Article received on June $4^{\text {th }} 2020$

Article accepted on June $5^{\text {th }} 2020$

Discussion and Polemics

UDC 069.9:782.038(492)"2019"

78.087.6:316.776.33

\title{
Ivana Ilić*
}

University of Arts in Belgrade

Faculty of Music

Music Theory Department

\section{Iva Nenić**}

University of Arts in Belgrade

Faculty of Music

Department of Ethnomusicology

\section{THE ANATOMY OF VOICE: TWO VIEWS ON THE EXHIBITION POST-OPERA \\ (“Tent" Gallery and "V2_Lab for the Unstable Media”, Rotterdam, April 19 - June 30 and May 3-26 2019) ${ }^{1}$}

\begin{abstract}
In this paper we discuss the exhibition Post-Opera, a complex and provocative curatorial project by Kris Dittel and Jelena Novak, in which the changeable relations between the voice and the (human) body are investigated from the creative and

* The author's contact details: ivana.ilic.stamatovic@gmail.com

** The author's contact details: genije@gmail.com

1 This paper was written under the projects "Identiteti srpske muzike u svetskom kulturnom kontekstu" [The Identities of Serbian Music in the World Cultural Context] (reg. nr. 177019) and "Muzička i igračka tradicija multietničke i multikulturalne Srbije" [Music and Dance Tradition of Multiethnic and Multicultural Serbia] (reg. nr. 177024), both financed by the Ministry of Education, Science and Technological Development of the Republic of Serbia, within the project cycle 2011-2019.
\end{abstract}


the theoretical perspectives, relying on juxtaposing and reflection between visual arts, technology and opera. Firstly, in the paper we examine the curatorial procedure, in its shift from the mediatory function between the work and the audience towards the practice, which intervenes in both of these domains and results in an exhibition as an autonomous art object. In the second part we interpret the politics and the effectiveness of the singing and the speaking voice in contemporary art and culture, while in the third part we write about the resemantization of the relation between the singing body and the sung voice within 'installing the operatic'.

Keywords: opera, post-opera, operatic, voice, body, singing machines

The exhibition Post-Opera is conceived and realized as a complex and provocative curatorial project that strived to investigate the ambiguous and changeable relationships between the voice and the (human) body, quite neglected in art theory until recently. It did so by bringing forward the juxtapositions and reflections between visual arts, technology and opera. In the process of their mutual networking the voice was posited as the exclusive signifier of the 'operaticness' of the opera itself, and the quality of voice and the body as equal in the process of the production of meaning. Having gathered both artists and art theorists, the exhibition Post-Opera provided the creative and the theoretical answers to the question "what is there/what remains outside of/after opera?", at the same time interrogating the discursive ramifications and the economy between these domains in contemporary culture and the art world. Since opera was set as the privileged point of departure for rethinking the voice-body relationship, it was omnipresent within this exhibition, disregarding the quality and the quantity of the traces which were left after it was first disassembled and taken apart and afterwards re-actualized in ways which leave the visitors all but indifferent, by means of different media and technological interventions and discursive strategies, within particular artistic poetics and theoretical platforms.

The exhibition Post-Opera is the result of a joint author-curator's work signed by the art historian Kris Dittel and the musicologist and the theorist of opera and media Jelena Novak. It included several segments which differed both in regard to their genre and media presentation: the staging of the exhibition in the gallery, periodical 'live activations' inside the exhibition space or in selected 'open' city locations, performances, a vocal workshop and a symposium. The main exhibition site was the "Tent" gallery - the symbol of urban Rotterdam culture, which is programmatically committed to contem- 
porary art. The second exhibition site was the interdisciplinary center for art and technology "V2_Lab for the Unstable Media".

The central and permanent part of the whole event assembled twelve works. All but one were exhibited in the "Tent" gallery. The majority consisted of sound/visual/multimedia installations commissioned specially for Post-Opera: Scores for Rotterdam by Mercedes Azpilicueta and John Bingham-Hall, a love poem by Franck Leibovici, The Audition by Tom Johnson performed at the Singing Machine (2010-2013) by Martin Riches, Opera of Things by Jasna Veličković, Reading 'Europe, Where Have You Misplaced Love?' by Katarina Zdjelar and Swarming Chants by Jan Adriaans. Two works were selected from the current artistic production: the interactive sculpture $A$ Truly Magical Moment (2016) by Adam Basanta and three-dimensional animation No Man II (2017) by Ho Tzu Nyen. The staging of the exhibition also included four drawings/illustrations/engravings dating from the mid-seventeenth to the early twentieth century.

The sound part of the installations was produced in three ways. For one group of works (Azpilicueta/Bingham-Hall and Veličković) it relied on the pre-ordered sequence adapted to the way the visitors walk through the gallery space. In the second group of works, the sound part was activated periodically either by the host, according to the number of visitors gathered (Riches/Johnson) or by the visitor her/himself when she/he would directly start the interactive sculpture (Basanta). In the third group of works the sound was continually broadcasted through headphones (Zdjelar, Leibovici) or loudspeakers (Nyen). Furthermore, some installations (Azpilicueta/Bingham-Hall, Riches/Johnson, Veličković, Adriaans) had their own 'live activations' several times during the exhibition, as it has already been said.

The exhibition Post-Opera also included performances, presenting BirdBecomeBird by Suzanne Walsh, How we learn the old songs by Paul Elliman, Solo Acoustic Performance by Janneke van der Putten and Empty Orchestra by Urok Shirhan. In this segment the exhibition also incorporated the vocal workshop Juicing Your Hole by Geo Wyeth. The one day symposium Installing the Voice (May 18) provided an explicit theoretical voice to the presented artworks. ${ }^{2}$ Theorists as well as some of the artists, whose works were a part of the exhibition program, took part in the symposium. By imprinting itself on the just twenty-year long history of voice studies, the symposium had the goal, as the title suggests, "to make the voice manifest, give it a place, put it into position, and set it up for analysis or experimentation".

2 The symposium was organized in collaboration with Operadagen Rotterdam. 
The exhibition Post-Opera consisted of heterogeneous elements activated in various ways and in various contexts, but it was not conceived as an event which each visitor had to experience as a whole. The curators counted on each visitor to make her/his own choice from the displayed content. We visited the opening evening of this exhibition in the "Tent" gallery, so we had the opportunity to directly experience only one part of it. On the basis of our direct impressions, as well as of subsequently observing several video recordings of 'live' performances, in this text we shall present our views on three key issues set in motion by the exhibition.

The curator as an artist / the exhibition as a form of art.

The curatorial procedure of the exhibition Post-Opera continues the high modernist and postmodernist interpretations of the relationship between the artwork and the technical-organizational conditions of its existence in the artworld today. Contrary to the traditional understanding of the role of the curator, who manages the space around the finished artwork 'from the outside' and offers it, in relation with other chosen artefacts, to a certain social group as a cultural value, Dittel and Novak acted 'from within' and the very process of the exhibition's birth, realization and presentation conceived in a way which enabled them to intervene in both domains. By relating the works selected from the current production and newly created commissioned works, the curators partly acted as mediators between the work and the audience in terms of the interpretation and organization of exhibiting the artwork. At the same time, by offering the platform for approaching the post-operatic artworld and culture, they also acted as conceptual catalysts of the creative process itself: having responded to the given thematic and problem coordinates of the exhibition, the artists (also) worked out the poetics of the exhibition itself as a specific artistic superstructure - the autonomous object presented to the audience.

Fully aware of the danger of an overly subjective interpretation of that object based on our own (musical) point of view, we could say that the exhibition had certain musical features as well, not only because each of its constituent parts, simply said, 'sounded'. Its internal sound texture was polyphonic and aleatoric, because the visitor as an active participant (performer?) had the opportunity, according to the possibilities predicted by the curators, to 'turn on' or 'turn off' certain vocal parts, thereby determining the density of that texture and the duration of individual parts, all that on top of a specific six-hour long bourdon, which is the duration of the $3 \mathrm{D}$ animation by $\mathrm{Ho} \mathrm{Tzu}$ 
Nyen. For the visitor this aleatoric polyphony was aesthetical fiction, but it is by all means ingrained in the method by which the exhibition was conceived.

The performance program and 'live activations' of the exhibited works within the gallery space provided a special performative dimension to that object. They additionally problematized, in the presentation of contemporary art, the ever more present practice that galleries literally take the performing arts under their own wing although they are initially neither conceived nor organized as their primary spaces. Thereby, this exhibition also investigated the relationship between the curator as an artist, the artist as a performer and the institution which enables these roles. For all the described reasons, the curatorial procedure in the exhibition Post-Opera was not based on a mere gesture of equality between the act of selection and the act of creation, but on the profound self-reflection of the exhibition process as much as on the creative and the performing process itself. That procedure showed not only that the relationship between these categories is not simple and unequivocal, but that it can be raised to the level of the poetical, as well as the methodological principle of the curatorial work as an artistic work.

In conceiving the exhibition as a specific form of art, the gallery space had a very important role. It was all but neutral. The traditional 'white cube', which radically suspends the spatial-temporal references of the artwork, was replaced by individualized visual solutions which, by means of their own characteristic features, entered into a signifying game between the work and its receiver. The curators reckoned with the tripartite nature of that relationship; they reckoned with the fact that the gallery is not only the necessary physical frame within which the visitor moves, but that the interaction between the visitor and the surrounding space is constitutive in the production of meaning. For example, the installation Scores for Rotterdam - the gallery translation of voice experiments recorded at selected Rotterdam sites (the metro station Wilhelminapier, the Maastunnel and the concrete forest beneath the railway viaduct at Mevlanaplein) - was placed on the ground floor of the building. One of the walls of this room contained windows stretching from the floor to the ceiling (Photograph 1). Therefore, the installation was (also) visible from the outside, literally from the street of the city sites and their voices were translated to the gallery context by means of the artistic gesture. The border between these two realities, the gallery, artistic one, on the one side of the glass, and the everyday city, on the other, was especially porous. Passing through the invisible bodies 'dressed' in textile while simultaneously so clearly present, available to the sense of hearing due to the voice 
they emitted, the visitor could also look outside the gallery, into the visible but inaudible bodies (also dressed in textile) only to receive the same glance back as belonging to the place it originated from. Voices without bodies and bodies without voices separated (or connected?) in the insecurity and ambivalence of their joint existence carry strong messages. Disturbing, even. They invite the visitors to reflect on the visibility and audibility of their own (in) secure and (un)equivocal existence, as well as on the voice as the privileged signifier of that existence.

Contrary to the described exposure of architecture and voices of the city, the multimedia installation a love poem by Franck Leibovici was set in almost complete darkness cut up by large hanging white canvases containing selected pages of the score (Photograph 2). The lighting was connected to individual music stands, which could be activated by the visitors, at will. The whole construction resembled a sound recording studio: music stands with scores on them, headphones, white gloves, small lamps and a hanging construction for the electricity supply. Here, the gallery space did not only function as the visitors' surroundings, but also as a specific defamiliarized scene. Namely, when the visitor approached the installation, turned on the lamp and put on

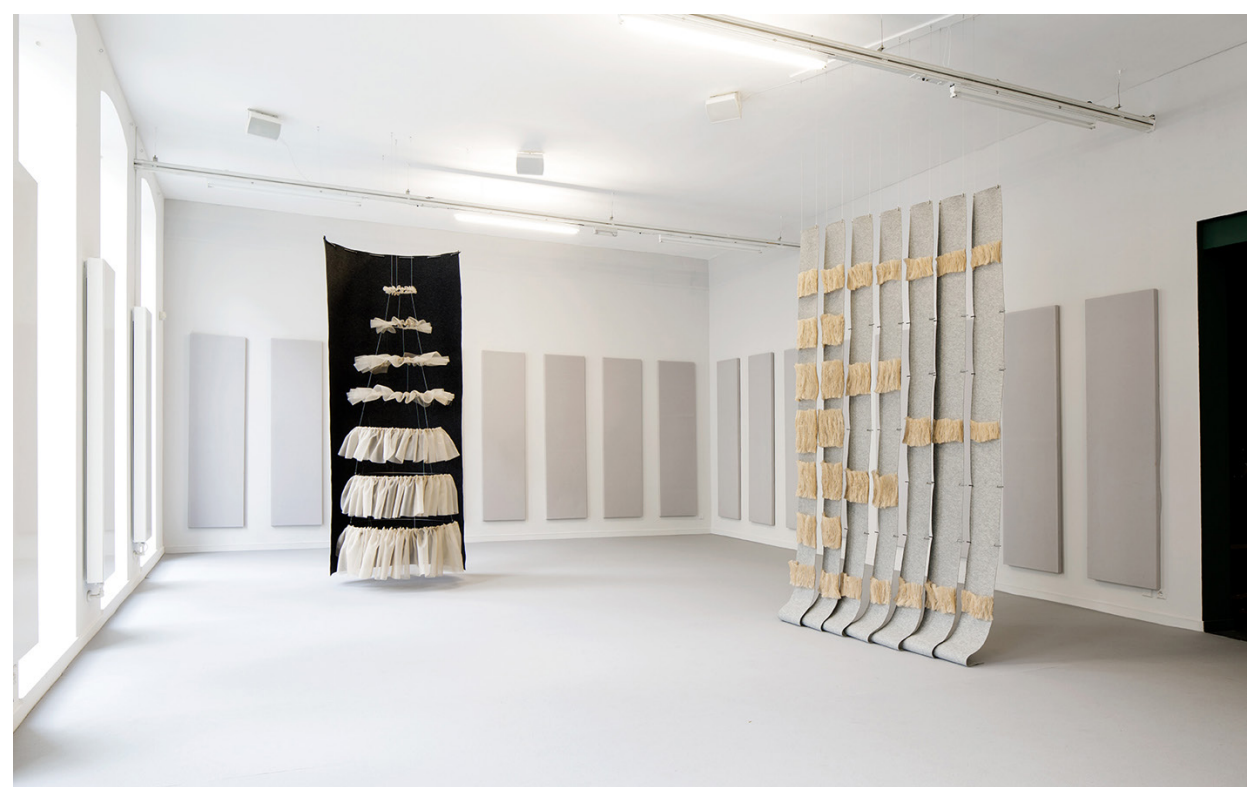

Photograph 1: Mercedes Azpilicueta \& John Bingham-Hall, Scores for Rotterdam (2019), installation with sound, photo by Aad Hoogendoorn 
the headphones, she/he would have in front of her/him the score created according to a highly provoking source (an amateur online porn video) and hear its performance - the vocalizations and the sounds of breathing. The contrast between the 'cold' technical elements, on the one hand, and the 'hot' textual and audio content, on the other, made the whole installation a very special experience. At the same time, the recipient would become a part of the installation: the one who is being looked at, while in the dark she/he reads and listens to a love song. All that, together with other visitors, who would, standing by other available music stands, join in the same game.

Here the manner of defamiliarization was conceived as a double game of reflections and their respective hierarchies: porn as the omnipresent, normalized love context of today with its cacophony of bodily sounds and the intoning' of lust, and the re-sounding or the distance of opera as the historical model delivered to the listener through the auditory media of the pornography. Going 'behind the scenes' or the disassembling of pleasure, its transformation into the musical language, also meant the employment of concrete, highly specialized techniques of scholarly and artistic work, such as the use

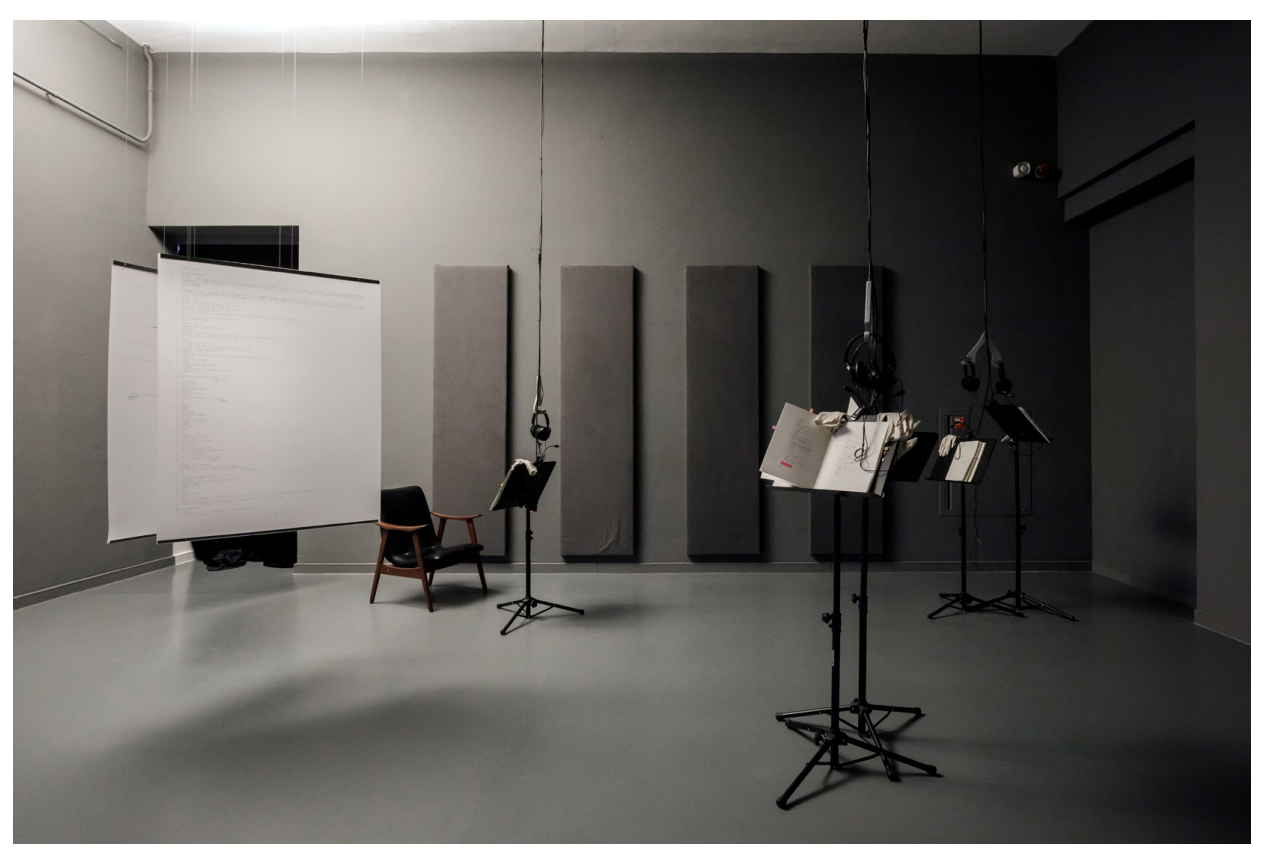

Photograph 2: Franck Leibovici, a love poem (2019), multimedia installation, photo by Aad Hoogendoorn 
of classical musical notation and ethnomusicological diacritics (in order to write down specific inflections, microtones, the 'agogics' of sex) or the visual suggestion of 'following' the score (sighs, mumbling, cries, meaningful pauses) during the listening, which is a skill musicians possess - exactly the same as sex, passion and arousal become technical skills which are practiced by learning and perfecting in the cold, radiant contexts of porn productions, but also in the assembled, craving 'immediacy' of sharing the amateur recording of sex, an almost panicky 'simulation after simulation'. Leibovici's work urges us to wonder about the dominant forms of listening in the early twenty-first century where we can - without stepping from the intimacy of our own room - actually take a step in any soundscape, be it historical, pop, seductively exotic, ancient. It seems that a voyeur simulation of the presence is lurking in that kind of listening, just like in the case with the 'reality' of a mediated sex tape. If, in the end, the score represents the translation of something quasi-intimate and unrepeatable in the technical and the notated, the technical-repetitive aspect of the recorded sexual act is simultaneously translated into an intimate homeboundness of the 'love song' in the trained voice (in the shift from the 'amateur' actor to the 'professional' singer), so these two categories appeared, a bit ironically, but in a certain sense profoundly, as fragile, interwoven and insecure, susceptible to time and fundamentally eroded by new ontologies of the visual and the auditory. The last, theoretical intervention with regard to this relationship was performed by framing the installation within the exhibition, where the darkness and the screen intended for one's solitary act of listening and observing, additionally reinforced the tension between the festive and the ironic, the affect hidden in the body and the simulation of the affect by the skilled operatic voice, the intimacy of the act of condensed listening and the extimacy of the seen (heard) sex, but also: the singing, the opera, the voice itself.

The domains of voice in contemporary art and culture.

One could clearly glimpse how the concept of the exhibition intended to question the delivery of the singing and the speaking voice, or the politicality / agency of the voice in the contemporary society and the media culture of over-stylized, polished, heavily processed chants of today. How does the voice work, then, as an intervention, representation, warning, especially bearing in mind its new, almost-perfect and mediated coat of immediate presence and hyperaesthetization? The video work by Katarina Zdjelar Reading 'Europe Where Have You Misplaced Love?' examines the possibility that in the interstice between singing and chanting, sounding of the poetic text and vo- 
cal amplification of the experience of marginalization and hard consequences of identity politics, a question regarding belonging and rejecting could be posed. This question also tackles the present crisis of the 'fortress of Europe' and highlights the marked position of the Other who does not stay mute, but who speaks out, criticizes, ironically questions. "Europe, every day white people spit after us on the subway. They seriously believe that the seats are their birthright. [...] Mina and Bahar have left, I don't think they'll come back." An open letter by Swedish poet Athena Farrokhzad addressed to Europe, confronts a well-known imago of Europe as a noble figure at the front of the progress of humanity, with the unsettling scenes of the drowned migrants on the shores of Mediterranean, the new rise of fascism and rejection on the basis of religion, ethnicity and race, while the spectre of Rosa Luxemburg "whispers that she is freezing". In an almost Derridean reading, Europe is presented as a mythical virgin whose body has been worn out, and whose potential for identity and political multivocality is just to be gambled away. ${ }^{3}$ This lyrical epistle by Farrokhzad is a powerful testimony of an unfulfilled promise, where the suppressed Others reveal themselves in their fullness, bitterness and rage. The relation of singing voices in the film by Zdjelar and the voices stemming from the poem's excerpt could be labeled as intertextual and complex, as it relies on the 'singing out' of those various voices from the margins, on reaching towards the Other without the intention of labeling her/him in accordance to some fixed identity. Zdjelar's work also relies on improvisation, murmuring, an instant synergy of musicians whose spontaneous 'rehearsal' in fact, gets to be made into an inscription, a performance interspersed by occasional scenes of children's playing. The music defies the fixture, as it crosses from short melodic motives in the instrumental parts to the repetition of one single tone that briefly sounds like an ostinato, and then becomes like a hint or a shadow of a melodic finalis with an upper minor second, as a possible allusion to the musically 'exotic'. But already in the next step, the music melts into a disturbing association on warning sirens, and then grows into a buzzing block of dissonances when the singer enters and starts to toy with the phrase "I don't think". Once more, it eludes the fixed reading when the melody changes into

\footnotetext{
3 "Maybe her name carries something that has no face yet? We hope, fear and tremble - what is she going to look like? [...] Is that the person Europe that we think we know?" (Jacques Derrida, L'autre cap /Drugi pravac/, transl. by Iva Nenić, Beograd, LAPIS, 1995, 10). Almost thirty years later after Derrida wrote this, Farrokhzad and Zdjelar basically repeat the same questions, only made acute by the different crises that subsequently came, without any dissolving point.
} 
something like a song with a guitar's accompaniment that hints the major / modal scale, and then it becomes scattered again, in a form of a whisper, trying out, almost like a quiet noise of the pre-symbolic. Here it is worth noting how Lacanian philosopher Mladen Dolar explains the political and ideological dimension of the voice as the presence that evades (identity, the logic of appropriation): "It is the voice which does not say anything, and the voice which cannot be said. It is the silent voice of an appeal, a call, an appeal to respond, to assume one's stance as the subject." 4 The layers of a singer's voice that buzzes, becomes stronger and then collapses into reciting textual fragments, singing without words, short recitatives and sighs, scattered indistinct sounds created by the creaking on the bodies of musical instruments, rhythmic 'ticking' on the cajon, together serve as a fleeting sign of the identity's evasion, of trauma and deprivation. These musical gestures approach matters of belonging not only in a political sense, but also with regard to the essential irreducibility of self and the impossibility to fully project the inner self into a firm collective identity, while simultaneously offering the occupation of a subject's position from the stance of the Other, through an injured, but own loudness, the substantiality of an evasive voice.

The visual part of the exhibition also suggests an interesting reading of the political dimension of the voice, by offering insights into certain historical approaches to listening and hearing, and on different mechanical prosthetics and machines that were meant to launch the sound from the place of its origin, in a literal and metaphorical sense. The displayed drawing by a Jesuit scholar, Athanasius Kircher, shows a device in a spiral shape (cochleato), a gigantic mechanical nautilus that connects the public square with the private chambers and brings the sound from the outside to a particular listener in his private space (a hall). This illustration was published in Kircher's renowned book A Dictionary of Music and Musicians/Musurgia Universalis (1650), a voluminous work that treats the phenomenon of sound in a post-scholastic way, typical of the $17^{\text {th }}$ century, by making a detailed inventory of the anatomy, history, aesthetics and metaphysics of musical sound and the sounds of nature. This book also carries the early seeds of the scientific approach to music, and anticipates the obsession with mechanical sound machines that was about to take Europe by storm. In Kircher's drawing, the voice of the public is shown in a frozen moment of transfer between the space of agora and private chambers,

${ }^{4}$ Mladen Dolar, $A$ Voice and Nothing More, Cambridge (MA) and London, The MIT Press, 124 . 
where the ruler has the exclusive privilege of eavesdropping on his subjects, but also of listening to the cacophony of sounds coming from outside. The 'output' that emits the gathered sound is drawn in the shape of a human statue that directly enunciates to the person of authority who has a privilege to listen. Kircher further developed the conception of this anthropomorphic automaton in his work Phonurgia nova, where he labeled statua citofonica. Placed in the current context of the omnipresence (and the illusion of 'owning') the 'world's sound' in the age of the Internet, this specific baroque linking of science and magic acquires new implications. ${ }^{5}$ Firstly, this faraway image of the sound automaton that transfers information (but also amuses) looks both innocent and ominous, when observed through the lenses of the technological clamour of the twenty-first century where the questions of the origin and the way of transmission of sound are habitually put aside by the mechanical act of consuming and without the possibility of verification of the sources. What does this warning consist of? Mostly, it refers to a call that the idea of the 'presence' of voice should be rethought, by raising the question of credibility of that which is heard, and whose invisible channels, twisted pathways and 'tubes' on a microscale, we habitually perceive as an authentic, accurate presence in a phenomenological, aesthetic, as well as in a political sense. Secondly, this drawing forces us to confront the uncanny sight of the disembodied voice, voice as an object, but also: to confront the impossibility of reaching the Other by a mere act of listening. Or, to again use Dolar's words: "If there is an empty space in which the voice resonates, then it is only the void of the Other, the Other as a void. The voice comes back to us through the loop of the Other, and what comes back to us from the Other is the pure alterity of what is said, that is, the voice."' The curatorial intervention in the form of confronting Kircher's depiction of the automaton that 'gathers' and amplifies the outer sound with the new sound machines that emit the voice at the exhibition, has several layers. Firstly, it is a display of an excerpt that documents the centuries-long craving to disassemble the voice, to transmit it and mechanically copy it. Then, it is an inquiry regarding the status of the voice-object, as a leitmotif that the whole exhibition relies on, and that strongly supports its theoretical framework. Finally, it is a warning that we are not always prone to

5 Cf.: Lamberto Tronchin et al., "The marvellous sound world in the 'Phonurgia Nova' of Athanasius Kircher", The Journal of the Acoustical Society of America, 123(5), 2008, 4187.

6 Mladen Dolar, op. cit., 160. 
critically approach the surveillance and manipulation (of voice) in the context of being a citizen, and that is a fact that must be taken into account in the context of the macro-infiltration of informational technology into everyday life, and especially in the light of the upcoming, even closer relations of bodies and machines that lurk on the horizon.

The audio installation and performance by Jan Adriaans deals with the affective and political qualities of the collective sound. If the voice was depicted as isolated and individualized in the works by Zdjelar and Kircher in regard of its emission and reception, Adriaans's installation Swarming chants aims to cut into the sonic pulsing of the large and spontaneous collectives and to highlight the relational nature of identity, by taking the sound of football fans' groups from various spots and then recombining that material into a sound object that gently sways without particular local, political and cultural references. In concordance with the thesis of the nature of 'multitude' in the biopolitical sense of a collective agency and subjectivity, Adriaans chooses to depict the sound of football crowds as the manifestation of a 'hive' logic, where individuality recedes, as a separate entity (a person) becomes a part of the manifold 'body without extremities'. The particularity of the individual voice dissipates, and the knowledge of the fact that the fans' repertoires are a specific bricolage of local and global fragments of pop culture, hymns, patriotic songs, children's chants, even some operatic excerpts, also starts to fade away. Instead, the gathered sound is treated as pure matter stripped of its original semantics that could be further molded and listened to in a different way. From the far standpoint of a distant observer, this chanting, humming, swaying looks like the almost rueful sounding of a massified social body that reaches us in an acousmatic manner, as a wave, the delocalized sound of a swarm, while the details of quarrels, political gestures and identity matters remain aside and those large structures that we either willingly or involuntarily throw ourselves into, became slowly visible. In a certain sense, a montage within Adriaans' work relates to the overall concept of the exhibition, because the use of the voice in/around/with regard to opera also can be observed from the 'top-down' position as a pattern or an interplay of several artistic outputs that are related in a (possible) configuration of the post-operatic, in a synthetic, playful and theoretically productive manner.

That today's collectives also rely on the displacement of the voice in the digital culture was the topic of a multimedia 3D installation No man II (2017) by Ho Tzu Nyen, with a digitally crafted choir made of almost fifty human, 
humanoid and post-human beings singing together. The animation was projected onto a large mirror glass that almost drew the spectator into the artist's 'secondary world' based on hybridized patterns of mythology and popular culture. If the work that was previously discussed started from the 'dehumanizing' of a human collective, here we see virtual people, anatomical figures, cyborgs, animals and chimeras with the hints of mythical, ethnic, racial and other origin, seemingly randomly gathered from the different corners of virtual worlds. They are shown as an integral part of the everyday, as our extensions scattered through history and through world cultures that demand to be recognized as a part of the humanity. Based on the immortal words of John Donne ("No man is an island entire of itself; every man is a piece of the continent, a part of the main..."), their singing consists of a prominent female vocal part, a dialogue of a female and male singer with a hint of a tonality, and also of a dense and freely treated choral texture that is solemnly delivered in a slow tempo. The work includes the artist's own point of view since it questions the placement of his own culture (Asian, Singaporean) in the world's context, and that can be observed in certain visual remarks, as well as in textual interventions (the word 'Europe' from Donne's lyrics was replaced with the word 'Malaya', an old name for a historical federation that once included Singapore). No man II calls for the reconsideration of the ways that we fictionalize, create, narrate different collectivities - at the very closure of the performance, the listener also appears as a reflection among the artificial singers in the mirror.

The singing body / the sung voice as an exhibition object: opera is on the stage (again)!

There is also a certain longing in the way in which opera, as the starting point of the whole exhibition, reached the visitors. Its departure from the institutional borders of the opera house and its entrance into the field of visual art, a specific 'installing of the operatic', took place along with the radical fragmentization and partial liquidation of its traditional elements. By focusing on the ventriloquist gap between the singing body and the sung voice, between that which is heard and which is seen on the opera stage and stepping, in the process of rethinking that relation, into the field of the automatized and/or technologically generated post- or transhuman world, the presented works have excitingly rethought the critical point of resemantization of the relationship between these two elusive, but for opera nevertheless constitutive elements,

7 Novak, Jelena, Operofilia, Beograd, Orion Art, 2018, 75-97. 
as that which "makes the opera operatic". That disassembled machine, whose voices become independent from the original source, simultaneously looking for the sound resonance and the sympathetic vibration of other surrounding audible and inaudible bodies, as well as for a compassionate emotion of its former listener-observer, brought - in a nostalgic reflection of its own 'grandiose' past - several interesting reinvestigations of the co-belonging and (de) synchronization of the voice and the body.

In Janeke van der Putten's performance one finds a trialogue between the voice which has already been produced and returns to its sender with the information both about itself and about the physical aspects of the performing space, the voice which is at the given moment in the process of transition, and the resonant body of the performer as the source and the recipient of sound. She moves within the space, listens as her voice travels and tries to detect what kind of message it returns to her and improvises monophonic and two-part vocalizations that sound human at one moment and completely dehumanized at the other, liberated from every direct referentiality. To say that this performance is virtuoso would completely miss the object, but the listening experience is very intensive: the voices which multiply the life pulse of their primary source, dispersing through space and filling it with almost tangible sonorous density, like an acoustic version of an electronic looping, the voices which at the same time sound out otherwise inaudible concrete walls thereby giving life to the non-living, exist on the magical horizon of reality and magic. Like human life itself, after all.

Exploring the border between the human body and the voice belonging to it, on the one hand, and the transformation, transposition and identification of that voice with the referentiality of non-human voices - animal (bird) in Suzanne Walsh's performance and signal sounds of emergency vehicles in Paul Elliman's work - on the other, reflected on how that border is not only thin, susceptible to intervention from the outside. And how intensive the human sensory experience of that intervention is. In Suzanne Walsh's performance, the rethinking of that border served to rethink the music itself. The performance includes the layering of audio materials (electronic sound, voice improvisations and musical phrases) in the unambiguously musical unfolding, starting from angel-like polyphonic euphony of the conjunct motion of female voices, through the gradual transformation of the human voice into bird chirruping and various concertante dialogues between the bird-like

${ }^{8}$ Jelena Novak, "Opersko (operatic), predlog za definisanje pojma”, in: Ibid., 75-78. 
chamber ensemble and the human/animal voice, to the texturally saturated twittering, cackling, cries, like the decisive utterance "I am (also) music!". In Paul Elliman's work the musical structure is also clear. It consists of the introductory solo, duet in the outer, and ensemble with the singled out soloist in the middle segment. The complex network of meanings of this work is woven on the basis of intentional gaps between the sound, the picture and the event, on the one hand, and unexpected correspondences which emerge between them, on the other. Emancipated from all 'standard' techniques which bring to light the mechanism and the 'vascularization' of the vocal apparatus of their host, the human voices are transformed into dehumanized machines: into howling sirens in which referentiality is everything but simple. The voice of the machine comes from the human body. But that voice is heard only when it comes to rescue - the human body. What is the key for interpreting this work? Who has the power over whom: the human body over the voice of the machine or the machine over the human voice and body? These questions are additionally emphasized with the scene quality of the performance itself, as the performers are mixed with the audience and start their performance unexpectedly, intervening in a given situation not only by means of the sound they produce, but also by means of their gestures and movements.

If as the listeners of Van der Putten and Walsh's works we could feel a certain enchanting magic of the human voice, in Elliman's work we could rather speak about a touch of awkwardness. It also marked the installation by Martin Riches and Tom Johnson (Photograph 3). Riches' Singing Machine is a synthetized voice produced by the machine supported by the operator (or: the mechanical device which produces something like the voice). During the opening night of the exhibition, when the appropriate number of listeners gathered, this singing device performed a short aria The Audition by Tom Johnson, conceived in such a way that it demonstrated the possibilities of the machine and, at the same time, with the necessary support of the score, that it offered a self-reflexive commentary of its kind, about the difficulties and aspirations of the (mechanical) singer who tried to 'make his way' to the opera scene. By producing the imitation of vocal vibrations of the human vocal apparatus, with the help of mechanical equivalents in the form of 'lips', 'larynx', 'tongue', this operatic Frankenstein sounded unheimlich. However, that sound is not mimetical and torn off the body as is the case with contemporary technologies that faithfully imitate the human voice: it is excitingly different homologous, but dissimilar, foreign, of an openly artificial materiality. With an octave ambitus and the possibility to articulate vowels (a, e, i, o, u), the 
Singing Machine is capable of performing short melodies whose textual part can be understood with the help of the score. Johnson's score contains syllabic sung verses, short recitativo segments that anticipate the desire of the machine to perform in the opera and cite its limitations ("I can only pronounce vowels"). This 'modesty' by the machine quickly converts into a witty statement that in the era of fast listening in which the individual does not dwell long on the music's text/score/historical surroundings which demand longer and deeper investment, 'intelligibility' often gets to be treated as collateral damage, in a literal and figurative sense ("So you have to read the text/But that is true in many operas today"). The machine demonstrates its technical and interpretive skillfulness by means of melismatic vocalizations performed in short rhythmic values to the words like 'fast' ("I can sing very fast"), or in long sustained tones (And for a long time on one breath), thereby iconically linking the verbal and the sound sign. One can observe that in this exhibition, based on the postulates of post-dramatic opera, the fragmentization and spectacularization of contemporary scenes are abolished and purposely resignified. The offering to an interested listener is not to be tricked - in the

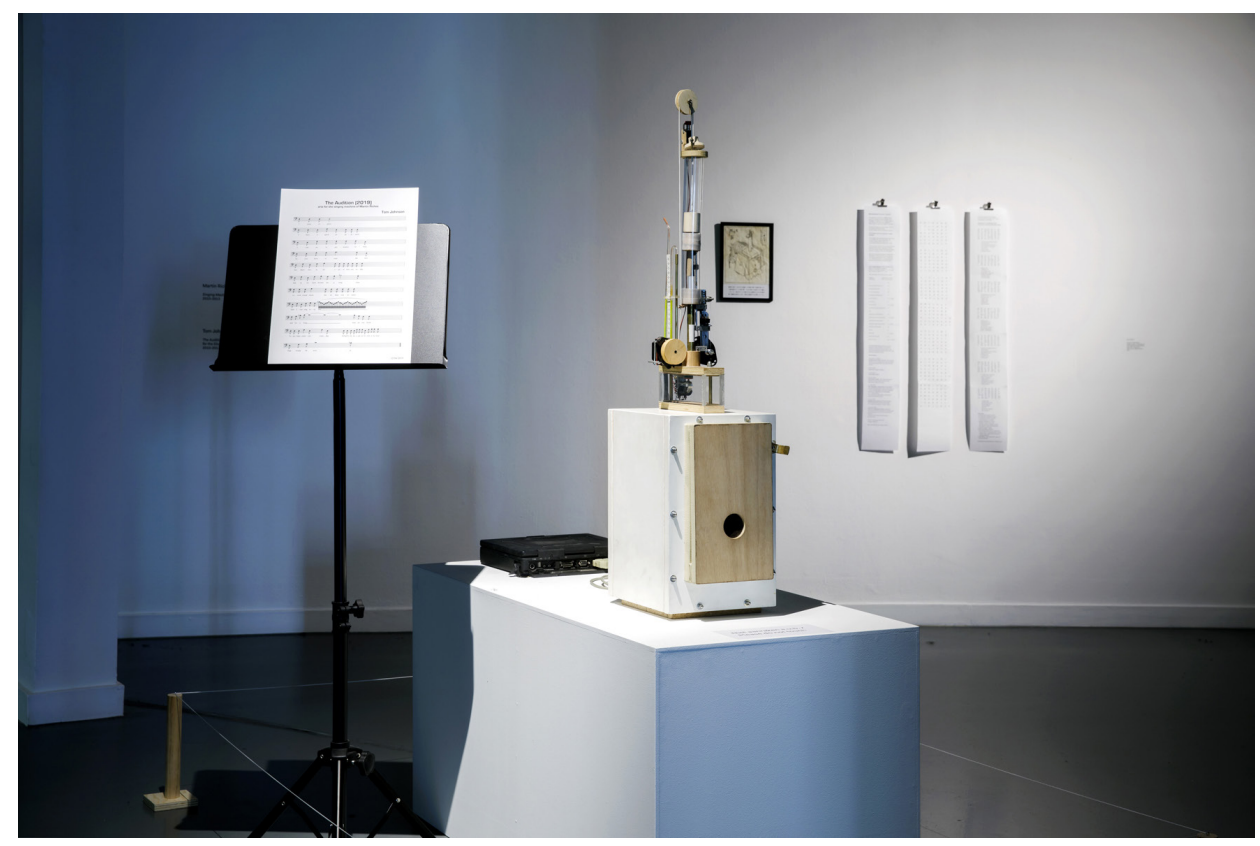

Photograph 3: Martin Riches' Singing Machine (2010-2013) performing the aria The Audition by Tom Johnson (2019), installation with sound, photo by Aad Hoogendoorn 
wrecks of the former listening and being in historical traditions of music - by the dominant, mediaized and 'polished' image of the operatic which often attempts only to reanimate the petrified image of the past, but, instead, to peep into side roads, to take a look at the developmental lines that freshly dive into the archive of the operatic past and thus try to grasp new and unusual alliances, such as the choir of human-machine voices.

That synthesized operatic voice is not, then, a homunculus hidden in the construction, but it can be a newly evoked animistic principle proclaimed by the 'singing' of the machine, whose voice is the completion of a distant dream, almost like the echo of Kircher's sketches, and in its (un)intelligibility, contrary to technological synthetizations of the human voice (think of 'speaking software'!) brought to a perfection, certainly somewhat magical.

The curators' networking of voices and the history of the mechanical production of the singing voice resonates in a specific way with the work by Jasna Veličković, in which the sublime, post-human potentiality of singing and voicing of inanimate objects is also questioned. Veličković's three-part installation Opera of Things originates from the concept "Internet of Things": just like the 'Internet of things' suggests the widening of the possibilities to transfer data over a network of everyday objects, mechanical and digital devices, in the same way the concept of voice in this work spreads outside of the domain of living beings to the sound produced by the electromagnetic field of devices (power adapters, remote controls). Three parts of the installation include the aria "Beauty 3.2 Volts" for power adapter, duet "Diva and the Beast" for Velicon, the instrument constructed by the composer herself, and female quartet "Ophelia" for four power adapters. These 'objects' - only in appearance silent and cold metal or plastic system units, but actually the treasuries of the most diverse kinds of sounds, from the almost tangible robust low, to the very profound and delicate high ones - received their voice through the composer/performer's movements. The uniqueness of these objects/instruments manifests itself in the fact that there is practically no pause in the production of musical sound: each movement of the artist generates some sound (Photograph 4 ). What is at stake here is radically rethinking the traditionally conceived performance: there is no expressive gesture, no affect, no emotion, no 'surplus' which transcends the raw mechanics of the tone production and offers itself as an aesthetic value of the performing act itself. There is the literal meaning of the roles of the bodies involved (the performer and the instruments) and their total, in a way magical, interdependence. The objectiveness, 
demasking, the presentness of the performing act engages the senses in a very special way: everything which is heard and seen becomes a part of music and everything is a part of the experience. That is why during the performance of these works the listener cannot close her/his eyes - not only like in the opera, but even more than that. One additional element in the mosaic of the rethought elements of music and/or opera is a complex polysemic relationship between the process of composing, improvisation, the composition as the finished product and performance, where the composing process is moved backwards and includes not only the decision about the choice of the object/ instrument, but also their disposition, which predetermines what is possible to produce, that is, what kind of sound and structure can be achieved. Once that is set, the composition/improvisation/performance come 'into play', intersect with each other, get to be mutually inscribed, making these levels of mutual convergence/divergence fluid. Hence, in accordance with the fact that to a certain degree each of these domains includes the element of the new, their resultant (the composition) is always different.

The installing of the operatic is realized in these works in one more way. Namely, 'the body' of the opera soloist/performer/power adapter was exhib-

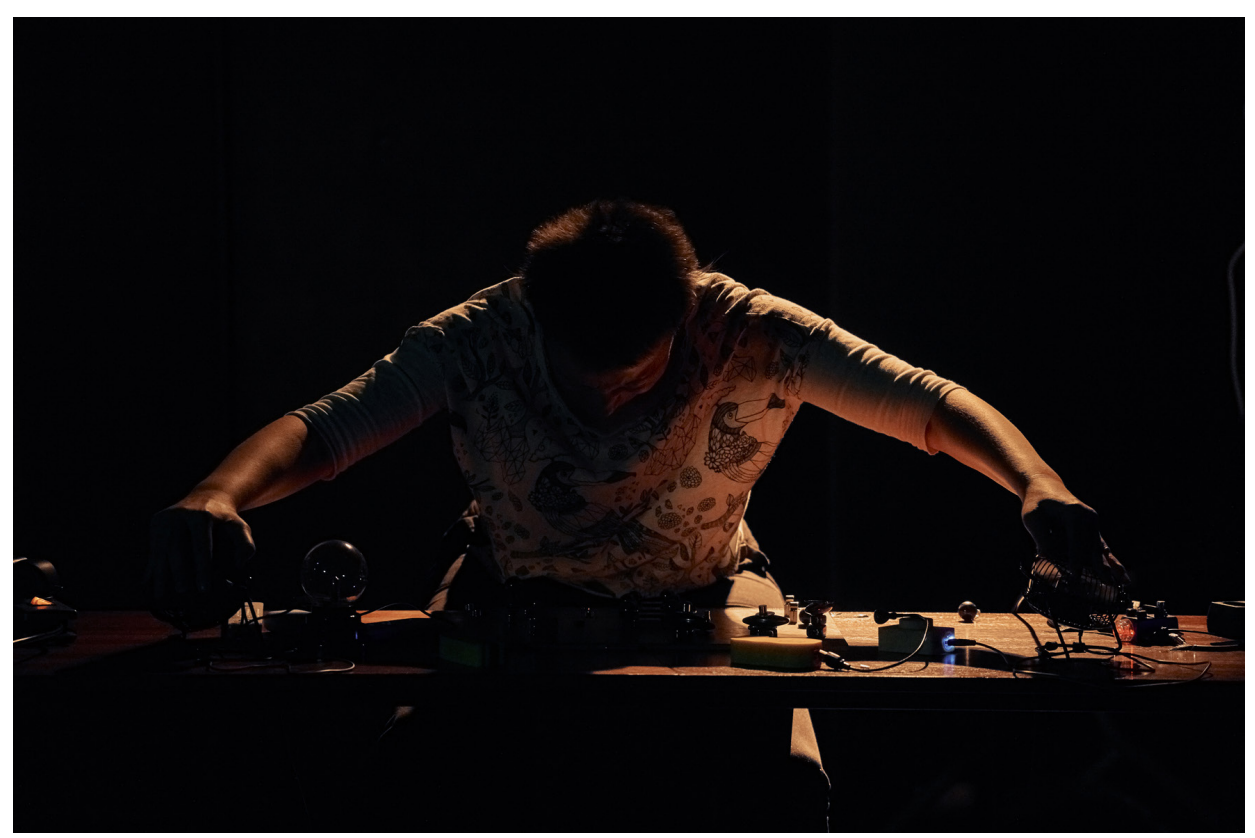

Photograph 4: Jasna Veličković performing Opera of Things (2019), photo by Yoon Kwan Hee 
ited in the same room as two anatomical drawings (1745-46) by Jacques Fabien Gautier d'Agoty, which realistically represent the anatomy of the vocal apparatus on one drawing, and the breathing apparatus on the other, with all the muscular and organic details, in the directness of the colour red. The quartet of power adapters was located in the immediate vicinity of the installation Singing Machine/Audition and the technical drawings for Riches' device, and the duet - in the same room as Kircher's drawing of sound automata, the reproduction of the engraving Sirènes a voyelles et résonatours buccaux (1900) by Georges René Marie Marage and the interactive kinetic sculpture $A$ Truly Magical Moment by Adam Basanta. In that way, three real little opera scenes emerged. Their voices/bodies had their two-dimensional silent antipodes, all that in a constellation which, in spite of all technological and media interventions, reshapings and disassemblings, powerfully pointed exactly to, as it is stated in the title of Basanta's work, true magic. For magic, according to Basanta, it takes a couple which wants to be (re)united, two iPhones, the FaceTime application, the Internet and only a minute of time: by dialing the given telephone numbers the couple starts the installation - the circular motion of mobile phones from the slow tempo to the fast and back - with a

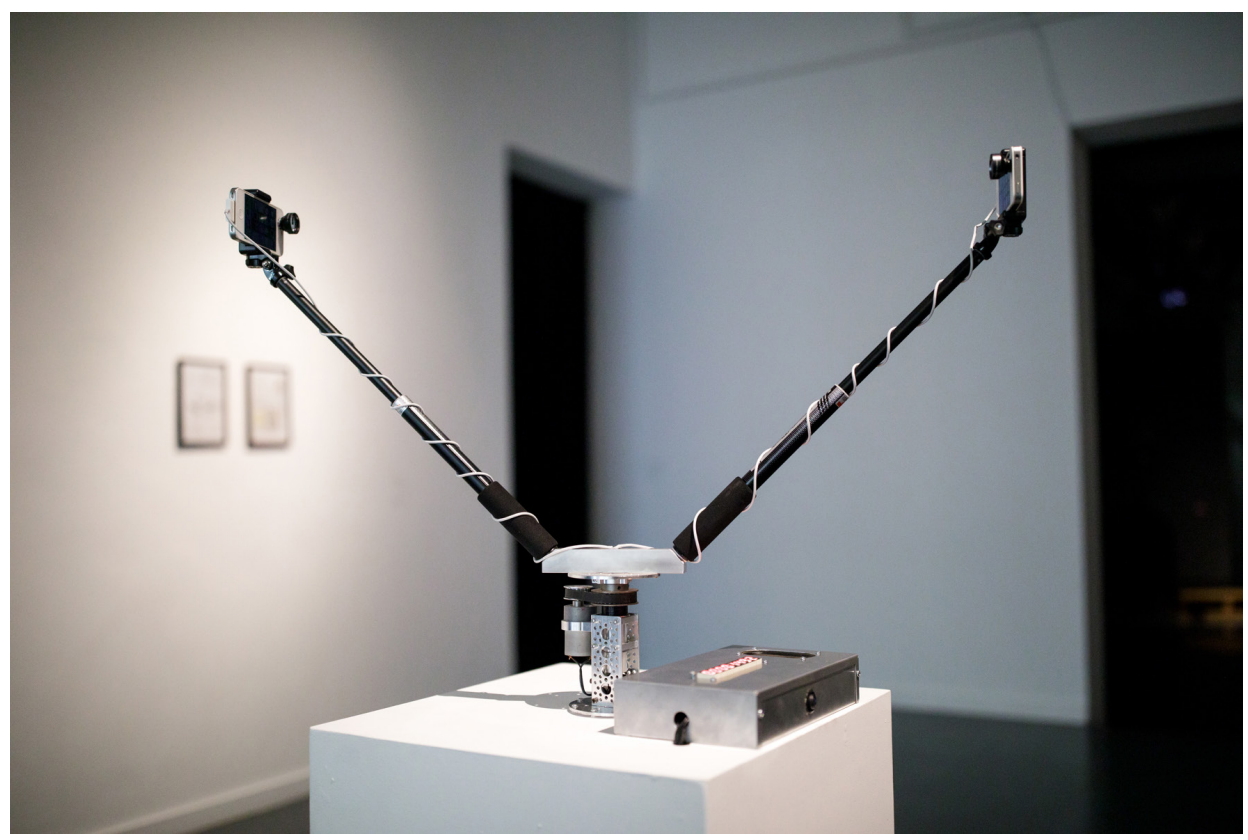

Photograph 5: Adam Basanta, A Truly Magical Moment (2016), interactive kinetic sculpture, photo by Aad Hoogendoorn 
succession of fragments from the Romeo and Juliet overture by Pyotr Ilyich Tchaikovsky, Madame Butterfly by Giacomo Puccini and the pop hit Reunited by Peaches and Herb. The mobile devices, with their screens facing each other, in a touching inversion re-enact cliché-like representations of couples in love who, while the world turns around them and time passes by, stare into each other's eyes, insensible of anything else but of each other (Photograph 5). That magical transfixation to the object of desire, which we almost somatically feel as our own, but which keeps slipping away from us further and further, may be considered the poeticized essence of this whole story about the voice which fled its (operatic) body. This story, mutatis mutandis, transposes itself onto the gaze and the ear of the visitor who has to (and can!) find her/his pair among the exhibited creations and surrender her/himself to the magic.

\section{Works cited}

Derida, Žak: Drugi pravac [Lautre cap]. Beograd: LAPIS, 1995.

Dolar, Mladen: Glas i ništa višse [A Voice and Nothing More]. Transl. by Iva Nenić. Beograd: Fedon, 2012.

Novak, Jelena: Operofilia. Beograd: Orion Art, 2018.

Tronchin, Lamberto et al.: "The marvellous sound world in the 'Phonurgia Nova' of Athanasius Kircher", The Journal of the Acoustical Society of America, 123(5), 2008, 4184-4190.

\section{Summary}

The exhibition Post-Opera is a complex and provocative project authored and curated by art historian Kris Dittel and the musicologist and the theorist of opera and media Jelena Novak. By bringing forward the juxtapositions and reflections between visual arts, technology and opera it strived to investigate the ambiguous and changeable relationships between the voice and the (human) body, quite neglected in art theory until recently. In the process of networking of those domains, the voice was posited as the exclusive signifier of the 'operaticness' of the opera itself, and the quality of voice and the body were put as equal in the process of the production of meaning. The exhibition included several segments which differed both in regard to their genre and media presentation: the staging of the exhibition in the gallery, periodical 'live activations' inside the exhibition space or in selected 'open' city locations, performances, vocal workshop and symposium.

Three key issues were launched by the exhibition. Firstly, the position of the curator as an artist and the exhibition as a form of art were taken into account. By making the shift from a mere gesture of equality between the act of selection and the act of crea- 
tion to the profound self-reflexion of the exhibition, the creative and the performing process, the curators raised the relationship between these categories to the level of the poetical as well as the methodological principle of the curatorial work as an artistic work. Secondly, the multifariousness of the domains of voice in contemporary art and culture was discussed: the delivery of the singing and the speaking voice, or the politicality / agency of the voice in the contemporary society and the media culture of over-stylized, polished, heavily processed chants of today. The voice appeared as the signifier of marginalization and serious consequences of identity politics, of power relations inherent in its disembodied presence, the invisible channels of its transmission and the receiver, of the relational nature of collective identities constructed both in everyday and digital 'reality'. Thirdly, the exhibition addressed the ventriloquist gap between the singing body and the sung voice as that which 'makes the opera operatic'. By stepping into the field of the automatized and/or technologically generated transor post-human world, the presented works have inspiringly rethought the critical point of resemantization of the relationship between these two elusive, but for opera nevertheless constitutive elements.

Translated by the authors 


\title{
Ивана Илић*
}

Чланак примљен 4. јуна 2020.

Чланак прихваћен 5. јуна 2020.

Научна критика, полемика

Универзитет уметности у Београду

Факултет музичке уметности, Катедра за музичку теорију

\section{Ива Ненић**}

Универзитет уметности у Београду

Факултет музичке уметности, Катедра за етномузикологију

\section{АНАТОМИЈА ГЛАСА: ДВА ПОГЛЕДА НА ИЗЛОЖБУ ПОСТ-ОПЕРА (ГАЛЕРИЈА „ТЕNТ“ И ,V2_LAВ FOR THE UNSTABLE MEDIA“, РОТЕРДАМ, 19. АПРИЛ-30. ЈУНИ И 3-26. МАЈ 2019. ГОДИНЕ) ${ }^{1}$}

\begin{abstract}
Апстракт: У раду се говори о изложби Пост-опера, комплексном и провокативном кустоском пројекту Крис Дител и Јелене Новак, у којем су у међусобном сапостављању и огледању визуелних уметности, технологије и опере, из стваларачке и теоријске перспективе истражене вишезначне, променљиве релације између гласа и (људског) тела. У првом делу рада сагледава се сам кустоски поступак, у помаку од његове посредничке функције између дела и публике ка пракси која интервенише у оба домена и резултира изложбом као аутономним уметничким објектом. У другом делу рада тумачи се политичност-дејственост певајућег и говорећег гласа у савременој уметности и култури, док су у трећем делу сагледане ресемантизације односа између певајућег тела и певаног гласа у оквиру „инсталирања оперског“.
\end{abstract}

Кључне речи: опера, постопера, оператично, глас, тело, певајуће машине

Изложба Пост-опера је замишљена и реализована као комплексан и провокативан кустоски пројект који је за циљ имао да у међусобном сапостављању и огледању визуелних уметности, технологије и опере истражи вишезначне, променљиве и у теорији доскора готово потпуно занемарене односе између гласа и (људског) тела. У мрежи која је у том процесу саткана глас је постављен као ексклузивни означитељ оператичности саме опере, а однос између гласа и тела као равноправан у процесу производње значења. Окупивши како уметнике, тако и теоретичаре уметности, изложба Пост-опера је понудила стваралачке и теоријске одговоре на питање „чега има/шта остаје изван/после опере?“" пропитујући, истовремено, дискуризвне оквире и економију односа између самих тих домена у свету савремене уметности и културе. Будући да је постављена као привилеговано исходиште промишљања релације гласа и тела, опера је на овој изложби била свеприсутна ма какви и ма колики да су били трагови који су остали након што је

\footnotetext{
* Ауторкина контакт адреса: ivana.ilic.stamatovic@gmail.com

** Ауторкина контакт адреса: genije@ gmail.com

${ }^{1}$ Овај рад је реализован у оквиру пројеката „Идентитети српске музике у светском културном контескту“ (бр. 177019) и „Музичка традиција мултиетничке и мултикултуралне Србије (бр. 177024) које финансира Министарство просвете, науке и технолошког развоја Републике Србије, у оквиру пројектног циклуса 2011-2019. 
она различитим медијским и технолошким интервенцијама и дискурзивним стратегијама, у оквирима посве особених ауторских поетика и теоријских платформи, најпре расклопљена и демонтирана, а потом наново актуелизована на начине који посетиоца не остављају равнодушним.

Изложба Пост-опера је резултат заједничког ауторско-кустоског рада који су потписале историчарка уметности Крис Дител и музиколошкиња и теоретичарка опере и медија Јелена Новак. Обухватила је неколико жанровски и медијски различитих сегмената: поставку у галеријском простору, периодичне „активације уживо“у простору изложбе, у простору галерије или на одабраним „отвореним“ локацијама града, перформансе, вокалну радионицу и симпозијум. У локацијском смислу, носилац изложбе била је галерија „Тент“ - својеврсни симбол урбане културе Ротердама, програмски опредељена ка савременој уметности. За други изложбени простор одабран је интердисциплинарни центар за уметност и технологију „V2_Lab for the Unstable Media“.

Централни и стални сегмент целокупног догађаја чинила је поставка изложбе: укупно дванаест радова од којих су сви осим једног били изложени у галерији „Тент“. Већински део поставке чиниле су звучне/визуелне/мултимедијалне инсталације поручене специјално за Пост-оnepy: Scores for Rotterdam Мерцедес Азпиликуете (Mercedes Azpilicueta) и Џона Бингам-Хола (John Bingham-Hall), a love poem (2019) Франка Леибовиција /Franck Leibovici/, The Audition (2019) Тома Џонсона (Tom Johnson) изведена на Singing Machine (2010-2013) Мартина Ричеса (Martin Riches), Opera of Things Јасне Величковић, Reading 'Europe, Where Have You Misplaced Love?' Катарине Здјелар и Swarming Chants Јана Адријанса (Jan Adriaans). Поставка је обухватила и два рада која су селектована из постојеће уметничке продукције: интерактивну скулптуру $A$ Truly Magical Moment (2016) Адама Басанте (Adam Basanta) и тродимензионалну анимацију No Man II (2017) Хо Цу Нјена (Ho Tzu Nyen). Наведеним радовима била су придружена и четири цртежа/илустрације/гравуре из периода од средине седамнаестог до самог почетка двадесетог века.

Звучни слој инсталација био је остварен на три начина. За једну групу радова (Азпиликуета/Бингам-Хол и Величковић) подразумевао је унапред утврђен временски распоред реализован у оквиру компјутерски програмираног lоора и прилагођен кретању посетилаца у галеријском простору. У другој групи радова звучни слој је био активиран повремено, када би то учинио или host рада за окупљен одређени број посетилаца (Ричес/Џонсон) или сам посетилац када би директно покренуо интерактивну скулптуру (Басанта). У трећој групи радова звук је био емитован континуирано, преко слушалица (Здјелар, Леибовици) или звучника (Нјен). Осим тога, поједине инсталације (Азпиликуета/Бингам-Хол, Ричес/Џонсон, Величковић, Адријанс) имале су и своје „активације уживо“, у неколико наврата током трајања изложбе, како је већ речено.

Изложба Пост-опера обухватила је и програм перформанса, у оквиру којег су били заступљени радови BirdBecomeBird Сузане Волш (Suzanne Walsh), How we learn the old songs Пола Елимана (Paul Elliman), Solo Acoustic Performance Јанеке ван дер Путен (Janneke van der Putten) и Empty Orchestra Урок Ширхан (Urok Shirhan). У овом сегменту, у изложбу је уврштена и вокална радионица Juicing Your Hole Џеа Вајета (Geo Wyeth).

Експлицитан теоријски глас представљеним уметничким радовима пружен је једнодневним симпозијумом под насловом Installing the Voice (18. мај) који је окупио 
како теоретичаре, тако и неке од уметника чији су радови били обухваћени изложбом. Уписујући се у тек око двадесет година дугу историју студија гласа, симпозијум је имао за циљ да, како му и сам наслов говори, „глас учини манифестним, да му да место, да га постави на позицију, и понуди као објект анализе и експеримента“.

Изложба Пост-опера је била сачињена из хетерогених елемената од којих су поједини били активирани на различите начине и у различитим контекстима, али она није била замишљена тако да је сваки посетилац мора видети у целости. Кустоскиње су рачунале с тим да ће свако заинтересован начинити сопствени избор из понуђеног садржаја. Ми смо ову изложбу посетиле на њеном отварању у галерији „Тент“, што значи да смо биле у могућности да непосредно сагледамо само један њен део. На основу искуства које смо том приликом стекле, као и на темељу појединих видео-снимака „живих“ извођења који су нам накнадно достављени, у наставку овог текста пружићемо наше погледе на три кључна проблема која је ова изложба покренула.

\section{Кустос као уметник / изложба као форма уметности.}

Кустоски поступак који стоји у основи изложбе Пост-опера наставља се на високомодернистичке и постмодернистичке реинтерпретације односа између уметничког дела и техничко-организационих услова његове егзистенције у свету уметности данас. Насупрот традиционалном схватању кустоса који „споља“ уређује простор око довршеног уметничког дела нудећи га, у релацији са другим одабраним артефактима, одређеној друштвеној групи као културалну вредност, Дител и Новак су деловале „изнутра“ и сам процес настајања, реализације и презентације изложбе замислиле тако да интервенишу у оба домена. Тиме што су у међусобну везу довеле радове селектоване из постојеће продукције и новонастале наручене радове, кустоскиње су у извесном степену наступиле као посредници између дела и публике у домену тумачења и организације излагања уметничког рада. Истовремено, понудивши платформу за приступ пост-оперском свету уметности и културе, оне су наступиле и као концептуални катализатори самог стваралачког процеса: одговарајући на задате тематске и проблемске координате изложбе, уметници су разрадили (и) поетику саме изложбе као својеврсне уметничке надструктуре, односно као аутономног објекта који је понуђен публици.

Свесне опасности од претераног уписивања сопствене (музичке) тачке гледишта у интерпретацију тог објекта, чини се да можемо рећи да је поставка изложбе имала и извесна музичка својства, и то не само због тога што је сваки њен чинилац звучао, најједноставније речено. Њено унутрашње звучно ткање било је полифоно и алеаторичко, јер је посетилац као активни учесник (извођач?) имао прилику да у оквиру могућности које су кустоскиње предвиделе „укључи“ или „искључи“ појединачне вокалне деонице, одређујући тиме густину тог ткања и трајање појединачних линија, и све то на својеврсном шестосатном бордуну, колико је трајала тродимензионална анимација Хо Цу Нјена. Та алеаторичка полифонија је за посетиоца естетичка фикција, али она постоји у методу којим је изложба настала.

Посебну перформативну димензију таквом објекту пружили су програм перформанса и „активације изложбе уживо“ који су се одигравали у простору галерије. Њима је додатно проблематизована, у представљању уметности све присутнија, пракса 
да галерије дословно узимају извођачке уметности под своје окриље иако иницијално нису замишљене нити организоване као њихови примарни простори. Тиме је овом изложбом пропитан и однос између кустоса као уметника, уметника као извођача и институције која те улоге омогућује. Из свих описаних разлога, кустоски поступак у изложби Пост-опера није почивао на пуком стављању знака једнакости између чина селекције и чина стварања, већ на дубинској ауторефлексији подједнако процеса излагања, колико и самог стваралачког и извођачког процеса. Показао је не само да однос између тих категорија није једноставан и једнозначан, него и да може бити издигнут како на ниво поетичког, тако и на раван методолошког принципа кустоског рада као уметничког рада.

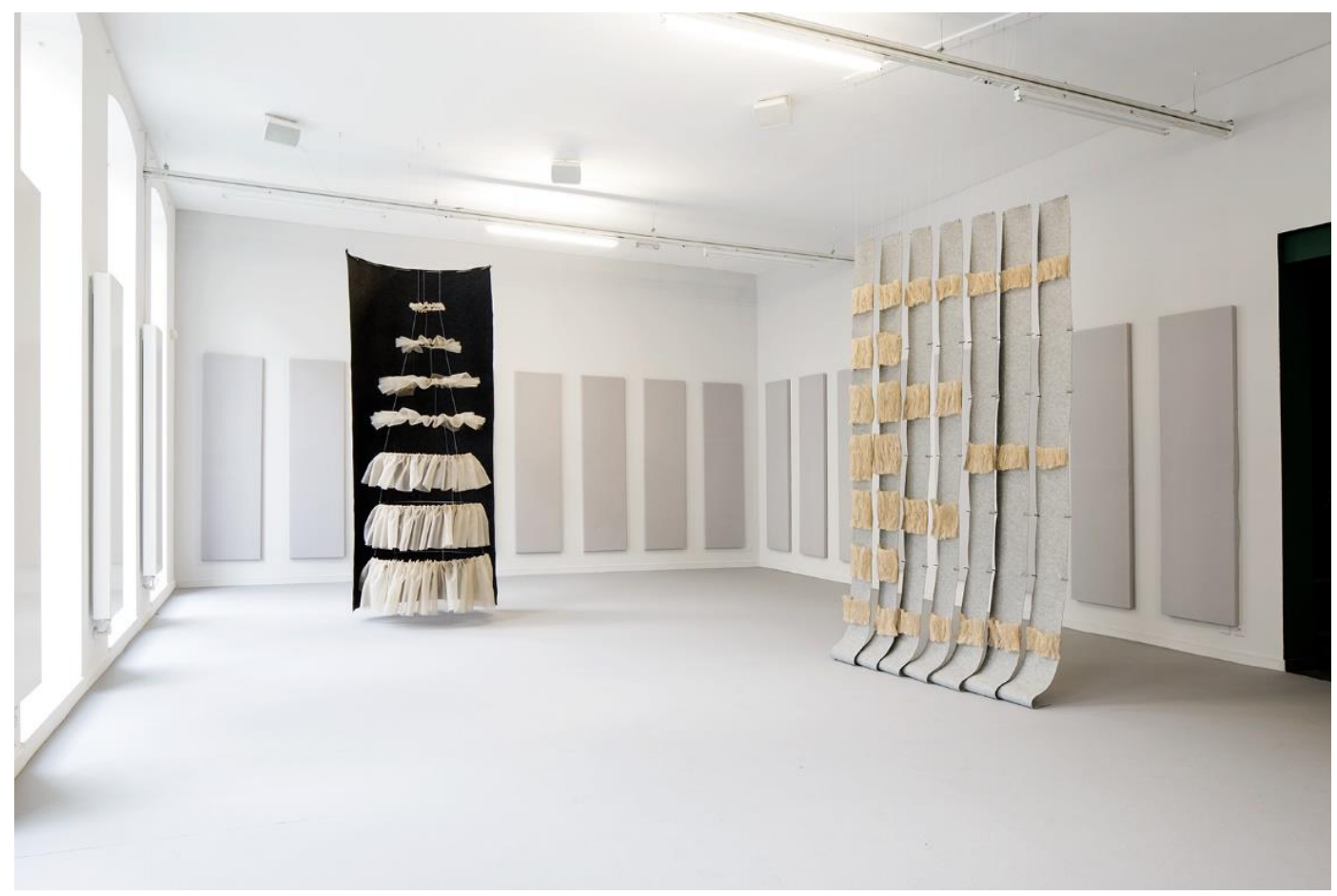

Фотографија 1: Мерцедес Азпиликуета и Џон Бингам-Хол, Scores for Rotterdam (2019), инсталација, [photo by Aad Hoogendoorn]

У реализацији изложбе као специфичне форме уметности, сам галеријски простор имао је важну улогу. Био је све само не неутралан. Традиционална „бела коцка“, која радикално укида просторно-временске референце уметничког рада, овде је била замењена индивидуализованим визуелним решењима која су својим карактеристичним својствима улазила у значењску игру између самог рада и његовог примаоца. Кустоскиње су управо рачунале на трострукост тог односа; рачунале су с тим да галерија није само неопходан физички оквир у којем се посетилац креће, већ да је интеракција између посетиоца и простора конститутивна у процесу успостављања значења. Тако је, на пример, инсталација Scores for Rotterdam („Партитуре за Ротердам“), као галеријски превод гласовних експеримената изведених на одабраним градским локацијама (метро станица, подводни тунел који повезује обале реке Мас, подножје железничког вијадукта), била смештена у приземљу здања, у просторији чији један зид садржи прозоре који се протежу целом његовом висином (Фотографија 1). Инсталација је тако била изложена (и) погледу споља, дословно са улице града чији су простори и њихови 
гласови уметничким гестом преведени у галеријски контекст. Граница између те две реалности, галеријске, уметничке, с једне стране стакла, и свакодневне градске, с друге стране, била је посебно порозна. Посетилац је могао, крећући се међу невидљивим телима „обученим“ у текстил а истовремено тако јасно присутним, доступним чулу слуха захваљујући гласу који су емитовала, да погледа и изван галерије, у видљива али нечујна тела (такође обучена у текстил) само да би му се тај поглед вратио назад као припадајући месту из којег је потекао. Гласови без тела и тела без гласова раздвојени (или спојени?) у несигурности и вишезначности заједничке егзистенције носе снажне поруке. Узнемирујуће, чак. Оне позивају посетиоца да се упита о видљивости и чујивости сопственог (не)сигурног и (више)значног постојања и о свом гласу као његовом привилегованом означитељу.

Насупрот описаној изложености архитектуре и гласова града, мултимедијална инсталација a love poem („Љубавна песма“) Френка Леибовиција била је постављена у готово потпуном мраку. Пресецала су га висећа бела платна великих димензија на којима су биле дате странице партитуре (Фотографија 2). Осветљење је било везано за појединачне пултове, а посетиоци су га могли активирати по својој вољи, све у оквиру конструкције која подсећа на студио за снимање звука: пулт, на њему партитура, слушалице, беле рукавице и лампица, и висинска конструкција за доток електричне енергије. Галеријски простор овде није деловао само као окружење посетиоца, већ и као својеврсна сцена, и то врло онеобичена. Наиме, када би посетилац приступио инсталацији, упалио лампицу и ставио слушалице, он би пред собом имао партитуру сачињену према крајње провокативном извору (посреди је аматерски онлајн порнографски видео) и чуо би њено извођење - вокализације и звуке дисања. Контраст између „хладних“ техничких елемената, с једне, и „врућег“ текстуалног и звучног садржаја, с друге стране, чинио је целокупну инсталацију потпуно посебним искуством. Истовремено, посетилац као реципијент рада постајао би и део саме инсталације: онај који је гледан док у мраку чита и слуша љубавну песму. И то заједно са другим посетиоцима који би, за неким од преосталих пултова, ушли у ту исту игру.

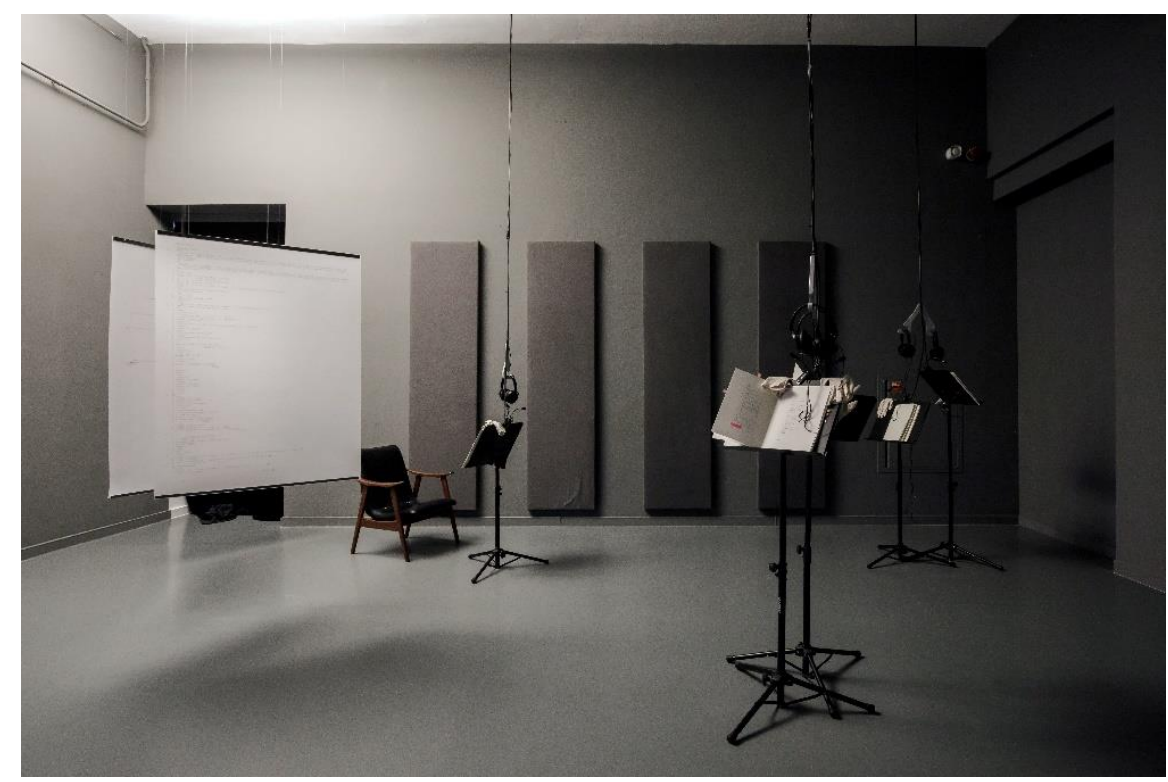

Фотографија 2: Френк Леибовици, a love роет (2019), мултимедијална инсталација, [photo by Aad Hoogendoorn] 
Поступак онеобичавања овде се указивао као двострука игра одраза и њихових хијерархија: порно као свеприсутни, нормализовани love контекст данашњице са својом какофонијом звукова тела и „интонирања“ сладострашћа, и од-звук или даљина опере као историјског предлошка који се предочава слушатељу/слушатељки кроз аудитивни медиј порнографског. Залажење „иза кулиса“ или: демонтирање задовољства, његова преобразба у музички језик, подразумевали су и упошљавање конкретних, високо специјализованих техника научног и уметничког рада попут употребе класичне музичке нотације и етномузиколошке дијакритике (како би се забележиле специфичне флексије, микротонови, „агогика“ секса) или визуелног сугерисања „праћења“ партитуре (уздаха, мрмљања, крикова, знаковитих пауза) током слушања, што је вештина коју поседују музичари - баш као што и секс, страст и помама постају техничке вештине које се упражњавају учењем и усавршавањем у хладним, сјајним контекстима порно продукција, али и у монтираној, чезнутљивој 'непосредности' дељења аматерског снимања секса, тој готово паничној „симулацији након симулације“. Леибовицијев рад нас подстиче да се запитамо ли се и у доминантним облицима слушања у раном XXI веку, где из интимности сопствене собе можемо - не крочивши - да заправо искорачимо у било које звуковље, историјско, поп, замамно егзотично, древно - заправо у бити крије једна воајерска симулација присуства, баш као што је има и сам медијски посредован sex tape? Ако је, на концу, сам партитурни предложак превођење нечег квази-интимног и непоновљивог у техничко и забележено, истовремено је и техничко-репетитивни аспект сниманог сексуалног чина преведен у интимну удомљеност „љубавне песме“ у тренираном гласу (у ходу од „,аматерског“ актера до „професионалног“ певача), па су се ове категорије указале, помало иронијски, али у извесном смислу и збиљски, као трошне, преплетене и несигурне, подложне трајању и темељно еродиране новим онтологијама визуелног и слушног. Последњи, теоријски завртањ овом односу, напослетку, дало је и смештање инсталације у контекст изложбе, где су мрак и платно намењени једном погледу и уху, додатно појачали тензију између свечаног и иронијског, афекта скривеног у телу и симулације афекта вештим, оперским гласом, интимности чина сведеног слушања и екстимности виђеног (чутог) секса, али и: певања, опере, гласа самог.

Домени гласа у савременој уметности и култури.

У концепту изложбе могла се јасно назрети упитаност над изрицањем певајућег и говорећег гласа, над политичношћу-дејственошћу гласа у савременом друштву и медијској култури престилизованих, полираних, heavily процесираних попевки данашњице. Како, дакле, глас делује као интервенција, заступање, опомена, поготово имајући у виду његову нову, готово-савршену и медијски посредовану опну моменталне презентности и хиперестетизације? Видео рад Катарине Здјелар Reading 'Europe Where Have You Displaced Love?' истражује могућност да се у простору између певања и запевања, озвучавања поетског текста и вокалне амплификације искуства маргинализације и разарајућих последица идентитетских политика, постави питање о припадању и одбачености, о пристиглој кризи унутар „тврђаве Европе“, о обележеној позицији Другог који није не̂м, већ проговара, замера, иронијски пропитује. „Европо, белци свакодневно пљују за нама у метроу. Они збиља верују да им седишта припадају рођењем. ... Мина и Бахар су отишли, не верујем да ће се враћати“ (Europe, every day 
white people spit after us on the subway. They seriously believe that the seats are their birthright. ...Mina and Bahar have left, I don't think they'll come back). Отворено писмо шведске песникиње Атене Фарокзад (Athena Farrokhzad) упућено Европи, добро знани imago Европе као узвишене фигуре-перјанице на прамцу развоја човечанства суочава са узнемирујућим призорима миграната-дављеника на Медитерану, поновним буђењем фашизма и одбацивања по верској, етничкој и расној основи, док нам сабласт Розе Луксембург „шапуће да се смрзава“. У сасвим деридијанском кључу, Европа се представља као митска девица чије је тело овештало, а њен потенцијал за идентитетску и политичку полифонију на ивици да буде прокоцкан, ${ }^{2}$ док је епистола коју је сачинила Фарокзад моћно сведочанство изневереног обећања, у којем се потиснути Други указују у својој пуноћи, огорчености и бесу. Однос певајућих гласова у филму Катарине Здјелар и забележених гласова које нам предочава поетски одломак јесте интертекстуалан и сложен, и подразумева испевавање тих различитих гласова са границе, посезање за Другим без тежње да му/јој се припише некакав фиксни идентитет, импровизацију, пој, читање и шапат/мрморење, тренутачну синергију четворо музичара чија спонтана „проба“ заправо и јесте произведена у запис, извођење, испресецано повременим кадровима дечје игре. Музика се опире фиксирању, прелазећи из кратких мелодијских мотива у инструментима у понављање једног тона, који на мах делује као остинато, а потом и као назнака (сенка) мелодијског финалиса са горњом малом секундом у виду конвенције „музички егзотичног“, да би се већ у наредном кораку претопила у узнемирујућу асоцијацију на сирене за опасност, и са уласком певачице која се поиграва фразом „I don’t think“, у брујећи блок дисонанци, а потом прешавши у назнаку песме подржане дурском / модалном звучношћу у деоници гитаре, поново се расула у шапат, испробавање, тиху буку предсимболичког. Овде ваља споменути како лакановски филозоф Младен Долар објашњава политичност и идеолошку ситуираност гласа као присуства које измиче (идентитету, логици присвајања) када каже: „То је глас који ништа не говори и глас који се не може изговорити. То је тихи глас апела, позива, апела да се одговори, да се заузме позиција субјекта““ ${ }^{3}$ Управо су слојеви које чине певачицин глас који бруји, јача па утихне изговарајући фрагменте текста, певање без речи и кратки речитативи, уздаси, „,расути“ шумови произведени шкрипом по корпусу инструмената и ритмички „откуцаји“ на кахуну, својеврстан одсев-знак идентитетског измицања, трауме и ускраћености - не само политичке, већ и суштинске несводивости оног унутрашњег у пројекцију чврстог идентитета и колектива, али и заузимања субјектне позиције са места Другог кроз једну рањену, али сопствену гласност, супстанцијалност измичућег гласа.

Занимљиву тезу о политичности гласа нуди и део визуелне поставке изложбе, подсећањем на историјске представе о слушању и чујењу, те на различите механичке „протезе“ и машине које ће помоћи да се звук отисне даље од места где је настао, у дословном и метафоричком смислу. Изложени цртеж језуитског научника Атанасиуса Кирхера (Athanasius Kircher) приказује уређај у облику спирале (cochleato), гигантски

\footnotetext{
${ }^{2}$ „Њено име можда носи нешто што још нема лице? Надамо се, страхујемо и дрхтимо - на шта ће личити? ... Је ли то она персона Европа коју мислимо да познајемо?“ (Žak Derida, Drugi pravac, Beograd, LAPIS, $1995,10)$. Готово тридесет година касније у односу на тренутак када је Дерида писао ове речи, Фарокзад и Здјелар у суштини понављају иста питања, само изоштрена различитим „кризама“ које су уследиле, без доласка неке тачке разрешења.

${ }^{3}$ Mladen Dolar, Glas i ništa više, Beograd, Fedon, 2012, 172. 
механички наутилус која спаја трг са приватним просторијама и доноси звук од споља једном слушаоцу у његовом личном простору (дворани). Илустрација је објављена у Кирхеровом знаменитом делу Речник музике и музичара - Musurgia Universalis (1650), вишетомном издању које на пост-схоластички начин карактеристичан за XVII век феномен звука третира у смислу подробног пописивања анатомије, историје, естетике и метафизике музичког звука и звукова природе, али и са назнакама раног научног приступа музичкој материји и опсесије механичким звучним направама која ће ускоро преплавити Европу. Овде је глас јавности приказан у „замрзнутом“ превођењу између простора агоре и личних одаја где владалац има ексклузивну привилегију да прислушкује поданике, али и да слуша какофонију других звукова који допиру од споља. „Излаз“ кроз који се емитује сакупљени звук приказан је у облику људске бисте која тако непосредно збори моћнику који је у позицији да слуша. Концепцију оваквог антропоморфног аутоматона Кирхер ће доцније развијати у делу Phonurgia nova под називом statua citofonica. Када се, међутим, смести у тренутни контекст свеприсутности и (илузије) поседовања „светског звука“ у доба Интернета, овај специфични барокни спој науке и магије стиче нове импликације. ${ }^{4}$ Најпре, овај далеки призор звучног аутоматона који преноси информације (али и забавља), сагледан на фону технолошке вреве двадесет првог века где се запитаност над пореклом и начином преношења звука најчешће потпуно потире у механичком чину конзумирања и без могућности верификације, делује истовремено невино и опомињуће. У чему се састоји опомена? Најпре, у позиву да се изнова премери идеја „присутности“ гласа, веродостојности онога што чујемо, а чије невидљиве канале, изувијане путеве и „тубе“ пренете на микронску скалу доживљавамо као аутентично, непатворено присуство у феноменолошком, естетском, па и у политичком смислу. Потом, цртеж нас тера да се суочимо са зазорним призором растеловљеног гласа, гласа као објекта, али: и немогућности да досегнемо Другог пуким чином слушања. Или, ако се опет послужимо Доларовим речима, ,ако постоји неки празан простор у којем глас одзвања, тада је то једино празнина Другог, Други као празнина. Глас нам се враћа кроз петљу Другог и то што нам се враћа од Другог јесте чиста другост онога што је изречено, односно глас“.5 Кустоска интервенција у виду суочења Кирхеровог приказа аутоматона који „прикупља“ и појачава спољни звук са новим звучним машинама које емитују глас приказаним на изложби, стога, функционише на неколико нивоа: најпре, као излагање исечка документације дуге историјске чежње да се звук растелови, пренесе и механички копира; потом, и као пропитивање статуса гласа-објекта, што јесте лајтмотив којим је проткана целокупна изложба и којим је снажно подупрт њен теоријски концепт; напослетку, и као опомињање на то да нисмо увек склони да се критички позабавимо надзирањем и манипулацијом (гласом) у контексту бивања грађанима, а о чему је нужно размишљати у светлу технолошко-информатичке макроинфилтрације у свакодневицу и пристижућих, још ближих односа телесно-машинског који су на хоризонту.

Афективно-политичка димензија колективног гласа предмет је обраде у аудио инсталацији и перформансу Јана Адрианса. Уколико у радовима Здјелар и Кирхера глас јесте приказан као изолован, индивидуализован, како у контексту емитовања, тако и

\footnotetext{
${ }^{4}$ Cf.: Lamberto Tronchin et al., „The marvellous sound world in the 'Phonurgia Nova' of Athanasius Kircher“, The Journal of the Acoustical Society of America, 123(5), 2008, 4187.

${ }^{5}$ Mladen Dolar, op. cit., 218.
} 
рецепције, Адриансова звучна инсталација под називом Swarming chants („Напеви ројења“) настоји да засече у звучно пулсирање великих и спонтаних колектива и једновремено укаже на релациону природу идентитета, узимајући звук навијачких група са разних места и рекомбинујући га у звучни објекат који се њише, лишен својих конкретних месних, политичких и културалних референци. На трагу тезе о природи „мноштва“ у биополитичком тумачењу колективног делујућег субјекта, Адрианс одабира да звук навијачких трибина прикаже као оспољење логике „роја“, где индивидуалност мора да устукне пред чињеницом да појединац постаје чинилац у склопу мноштвеног ,тела без удова“. Појединачност индивидуалног гласа чили, као што и бледи чињеница да су навијачки репертоари специфични бриколаж локалних и глобалних исечака поп културе, химни, патриотских песама, дечијих напева, па чак и појединих оперских одломака - звук се третира као материја којој је одузета првобитна семантика, и који стога постаје сонорна пластика која се може додатно обликовати и другачије ослушнути. Из удаљене тачке коју рад заговара, то запевање, брујање, гибање делује као готово сетно оглашавање једног омасовљеног тела које до нас допире акузматички у виду таласа, делокализованог звука роја, и где се појединости препирања, политичких порука и идентитетских изрицања губе у корист великих структура чији смо (вољни или невољни) део. У извесном смислу, монтажа присутна унутар Адриансовог рада одражава и концепт саме изложбе у којем се употреба гласа у/око/поводом опере такође из посматрачке позиције „одозго“ може сагледати као патерн или међусобна игра више уметничких остварења повезаних у синтетском, игривом и теоријски производном маниру у (могућ) образац пост-оперског.

Да данашњи колективи претпостављају и измештеност гласа у дигиталну културу, приказао је хор сачињен од близу педесет људских, хуманоидних и постхуманих бића која скупа певају у мултимедијском 3D остварењу No Man II (2017) Хо Цу Нјена, анимацији пројектованој на велику огледалну површину која као да „увлачи“ посматрача у уметников „секундарни свет“, поникао на хибридном споју митолошких матрица и популарне културе. Ако се у претходно поменутом раду људски колектив у извесном смислу дехуманизовао, овде су виртуелни људи, анатомске фигуре, киборзи, животиње и химере са назнакама митског, етничког/расног и сваког другог порекла, који делују као да су насумично прикупљени из различитих кутака виртуелних анимираних светова, приказани као интегрални део свакодневице, као наше екстензије расуте кроз историју и културе које потражују своје право на припадност човечанству. На бесмртне стихове Џона Дона ${ }^{6}$ (John Donne) (Ниједан човек није острво, само по себи целина / Сваки је човек део Континента, део Земље...), њихово певање изведено је у преплету истакнуте солистичке деонице поверене певачици, дијалога женског и мушког гласа са овлашним назнакама тоналности, те густог и слободно третираног хорског слога, у лаганом темпу и на свечан начин. Рад укључује личну тачку гледишта уметника у смислу пропитивања смештености његове сопствене културе (азијске, сингапурске) у свет који делимо, што се може сагледати у извесним визуелним назнакама, али и текстуалним интервенцијама (у одломку Доновог текста, реч „Европа“ мења се речју „Малаја“ што је стари назив за федерацију која је укључивала и Сингапур). No man II такође позива на сагледавање начина путем којег фикционализујемо, стварамо,

\footnotetext{
${ }^{6}$ Стихови су преузети из Доновог прозног рада Devotions upon Emergent Occasions-Meditation XVII (1624). 9
} 
приповедамо (а онда, и певамо) различите колективе - на самом крају извођења, и слушалац/слушатељка појављује се као одраз међу ликовима у огледалу.

\section{Певајуће тело/певани глас као изложбени објект: опера је (поново) на сцени!}

Извесне сете има и у начину на који је опера, као исходишна тачка целокупне изложбе, допирала до посетилаца. Њен излазак из институционалних граница оперске куће и улазак у поље визуелних уметности, својеврсно „инсталирање оперског“, 7 догодило се уз радикалну фрагментаризацију и делимичну ликвидацију њених традицијом установљених елемената. Постављајући у фокус вентрилоквистички јаз између певајућег тела и певаног гласа, између онога што се чује и онога што се види на оперској сцени и искорачујући у преиспитивању те релације у простор аутоматизованог и/или технолошки генерисаног транс- или постхуманог света, представљени радови су на узбудљив начин преиспитали критичну тачку ресемантизације односа између та два елузивна, али за оперу ипак конститутивна елемента, као онога што 'оперу чини оперском' ${ }^{8}$ Та расклопљена машина, чији гласови се осамостаљују од извора који их је произвео, тражећи при том звучну резонанцу и симпатетичку вибрацију других окружујућих звучних и безвучних тела, као и емпатичну емоцију свог некадашњег 'гледајућег слушаоца', донела је - у носталгичном одразу сопствене 'грандиозне' прошлости - неколико занимљивих преиспитивања саприпадности и (де)синхронизованости гласа и тела.

У перформансу Јенеке ван дер Путен на делу је тријалог између гласа који је већ произведен и враћа се свом пошиљаоцу са информацијом како о себи тако и о физичким својствима изведбеног простора, гласа који је у датом тренутку у процесу одашиљања, и резонантог тела перформерке као извора и реципијента. Она се креће простором, ослушкује како њен глас путује и какву информацију јој враћа натраг и на лицу места импровизује једногласне или двогласне вокализације које звуче час хумано, час потпуно деуманизовано и, чак, ослобођено од сваке директне референцијалности. Казати да је ово извођење виртуозно у потпуности би промашило објект, а, опет, слушно искуство је веома интензивно: гласови који умножавају животни пулс свог примарног извора распршујући се простором и испуњавајући га готово опипљивом сонорном густином попут некакве акустичне верзије електронског лупинга, и који истовремено озвучавају иначе нечујне бетонске зидове дајући живот неживом, егзистирају на магичном хоризонту реалности и магије. Попут самог хуманог живота, уосталом.

Истраживање границе између људског тела и њему припадајућег гласа, с једне, и трансформације, транспозиције и идентификације тог гласа са референцијалношћу нехуманих гласова - анималних (птичјих) у перформансу Сузане Волш и сигналних звукова возила хитних служби у раду Пола Елимана - с друге стране, покренуло је размишљања о томе колико је та граница не само танка, него управо подложна интервенцији споља. И колико је интензивно човеково чулно искуство те интервенције. У перформансу Сузане Волш преиспитивање те границе је стављено у службу преиспитивања саме музике. Перформанс подразумева наслојавање звучних материјала (електронског звука, гласовних импровизација и музичких фраза) у недвосмислено

\footnotetext{
${ }^{7}$ Novak, Jelena, Operofilia, Beograd, Orion Art, 2018, 75-97.

${ }^{8}$ Jelena Novak, „Opersko (operatic), predlog za definisanje pojma“, u: Ibid., 75-78.
} 
музичком одвијању од квазианђеоске полифоне еуфоније поступно вођених деоница женских гласова, преко постепене трансформације хуманог гласа у птичји цвркут и разноврсних концертантних дијалогизирања птичјег камерног ансамбла и хуманог/анималног гласа до фактурно засићеног цвркутања, гакања, крикова, попут одлучног изричаја „(и) ја сам музика!“. У раду Пола Елимана музичка структура је такође јасна. Чине је уводни соло, дует у оквирним и ансамбл са издвојеним солистом у средишњем сегменту, а сложена значењска мрежа овог рада плете се на основи намерних прекида између звука, слике и догађаја, с једне, и неочекиваних кореспонденција које се међу њима јављају, с друге стране. Еманциповани од свих „стандарндих“ техника које износе на видело механизам и „прокрвљеност“ вокалног апарата свог домаћина, хумани гласови се у овом раду преображавају у дехуманизоване машине: у завијајуће сирене, чија референцијалност је све само не једноставна. Глас машине долази из људског тела. Али, тај глас се иначе чује само онда када долази у спас - управо људском телу. У ком кључу читати овај рад? Ко има власт над ким: људско тело над гласом машине или машина над људским гласом и телом? Ова питања су додатно потцртана сценичношћу саме изведбе, будући да су извођачи помешани с публиком и започињу извођење ненадано, интервенишући у неку текућу ситуацију не само звучно, већ и гестом и кретањем.

Ако смо као слушаоци у радовима Ван дер Путенове и Волшове могли да осетимо извесну очаравајућу магију човековог гласа, у Елимановом раду пре бисмо могли говорити о дози нелагоде. А она је обележила и инсталацију Мартина Ричеса и Тома Џонсона. Ричесова Singing Machine је синтетизовани глас произведен машином уз подршку оператера (или: механички уређај који производи нешто налик гласу) (Фотографија 3). На отварању изложбе ова певајућа справа је у неколико наврата, када се окупи одговарајући број слушалаца, изводила кратку арију The Audition Тома Џонсона, осмишљену тако да демонстрира могућности машине, а уједно и да, уз неопходну подршку партитуре понуди својеврстан ауторефлексивни коментар о мукама и тежњама (механичког) певача који покушава да се „пробије“ на оперској сцени. Производећи имитацију вокалних вибрација људског говорног апарата, уз помоћ механичких еквивалената у виду „усана“, „ларинкса“, „језика“, овај оперски Франкенштајн звучи unheimliche, но тај звук није миметички и отргнут од тела као у случају савремених технологија што верно опонашају људски глас, већ узбудљиво несличан - хомологан, а опет друкчији, туђински, отворено артифицијелне материјалности. Са амбитусом октаве и могућношћу да артикулише самогласнике (a, e, и, о, у), Singing Machine је у стању да изведе кратке мелодије, чији се текст може разумети уз помоћ партитуре. У Џонсоновом распису то су силабични певани стихови, кратки речитативни одломци који најављују жељу машине да наступа у опери и указују на њена ограничења (I can only pronounce vowels), премда се ова скромност премеће у духовито констатовање да је у ери брзог слушања у којој се не застаје дуже над текстом/партитуром/историјским окружјем музике који захтевају дуже и дубље инвестирање, „разумљивост“ често колатерална штета, у дословном и пренесеном значењу (So you have to read the text/But that is true in many operas today). Машина демонстрира и своју техничку и интерпретацијску спретност мелизматичним вокализама изведеним у ситним ритмичким вредностима на речима попут „брзо“ (I can sing very fast), или дугим држаним тоновима (And for a long time on one breath), 11 
успостављајући тиме иконички однос између вербалног и звуковног знака. Примећујемо да се фрагментираност и спектакуларизација присутни на сценама данашњице, у поставци ове изложбе заснованој на постулатима пост-драматске опере, укидају и сврховито презначују, нудећи заинтересованим слушаоцима/слушатељкама да у развалинама некадашњег слушања и бивања у историјским традицијама музике, не наседну на доминантну, медијску и ,углачану“ слику оперског која често настоји тек да реанимира окамењену слику прошлости, већ да, уместо тога, завире у бочне путеве, осмотре линије развоја које на свеж начин урањају у архив оперске прошлости, те тако и ослушну нове и несвакидашње савезе, попут хора људско-машинских гласова.

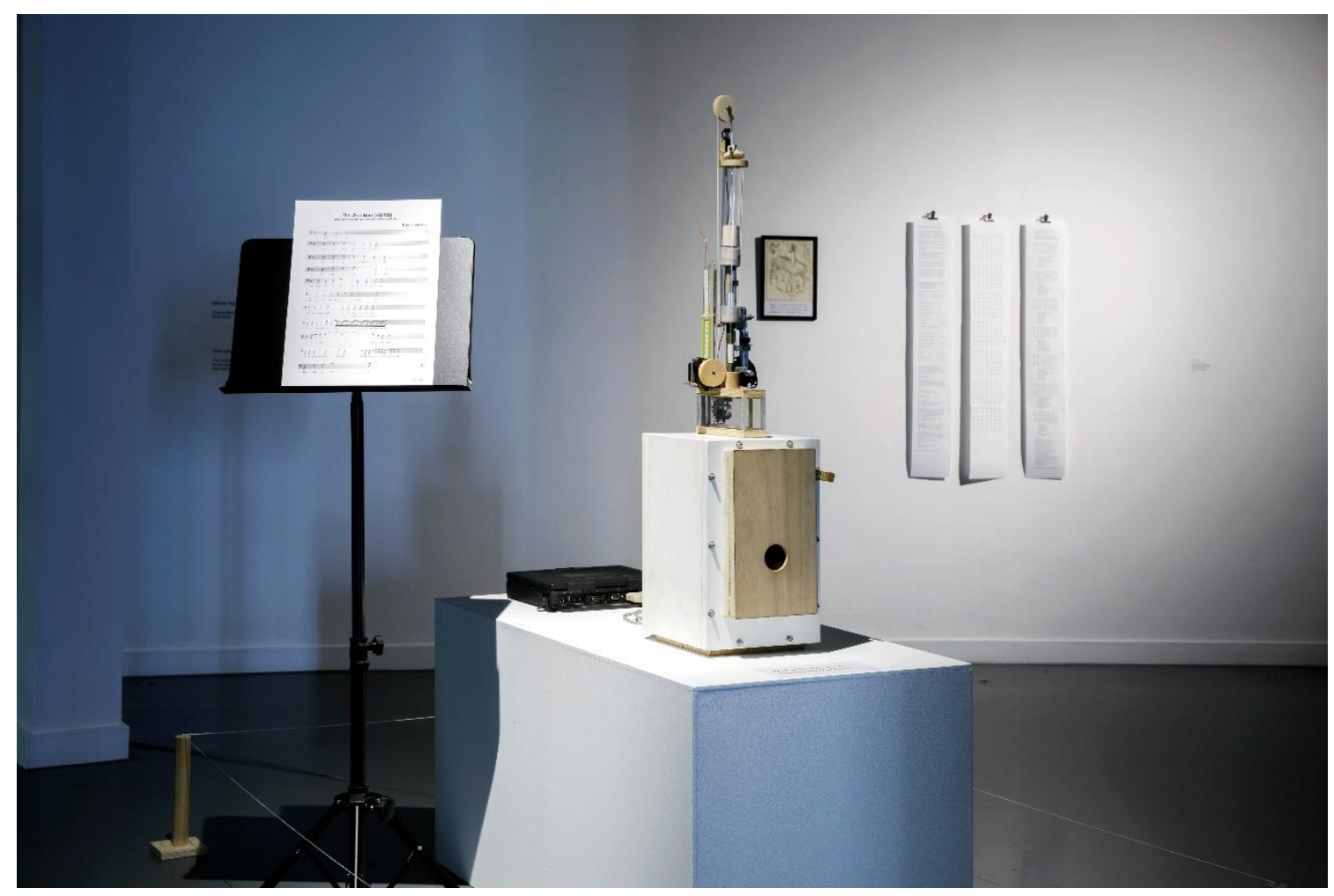

Фотографија 3: Мартин Ричес, Singing Machine (2010 -2013) изводи арију The Audition Тома Џонсона (2019), инсталација, [photo by Aad Hoogendoorn]

Тај синтетизовани оперски глас није, тада, хомункулус скривен у конструкцији, већ може бити изнова призван анимистички принцип који се обзнањује „певањем“ машине, и чији је глас довршење једног далеког сна, попут одјека Кирхерових скица, а свакако и, за разлику од до савршенства доведених технолошких синтетизација људског гласа (сетимо се само „говорећих софтвера“‘), у својој (не)разумљивости помало и магичан.

Кустоско умрежавање гласова и историјата механичке производње певајућег гласа специфично резонира и са радом Јасне Величковић, у којем се такође пропитује сублимни, пост-хумани потенцијал певања и гласања неживих објеката. Троделна инсталација Opera of Things („Опера ствари“) Величковићеве происходи из концепта „Internet of Things“: као што „интернет ствари“ подразумева ширење могућности преноса података на мрежу свакодневних предмета, механичких и дигиталних уређаја, тако се у раду Величковићеве концепт гласа проширује изван домена живих бића на 
звуке које прозиводи електромагнетно поље уређаја (пуњача, даљинских управљача). Три дела инсталације обухватају арију „Лепотица 3.2 Волта“ за пуњач, дует „Дива и Звер“ за великон, инструмент који је конструисала сама композиторка, и женски квартет „Офелија“ за групу пуњача. Ови „предмети“ - само наизлгед нема и хладна метална или пластична кућишта, а заправо ризнице најразлчитијих зувкова, од готово опипљиво робустних ниских, до врло финих и деликатних високих - добили су свој глас путем покрета композиторке/перформерке. Посебност тих предмета/инструмената јесте, поред осталог, у томе што у производњи музичког звука практично нема паузе: сваки покрет уметнице генерише неки звук (Фотографија 4). Посреди је радикално преосмишљавање традиционално схваћеног извођаштва: нема експресивног геста, нема афекта, нема емоције, нема никаквог „вишка“ који трансцендира сирову механику производње тона и нуди се као естетска вредност самог извођачког чина. Овде је на делу дословност улога инволвираних тела (перформерке и инструмента) и њихова тотална, унеколико и магична, међузависност. Објектност, демаскирање, презентност самог извођења на посебан начин активира чула: све што се чује и види постаје део музике и све је део доживљаја. Стога се на извођењу ових радова не могу затворити очи - не само као у опери, него и више од тога. Још један елемент у мозаику преосмишљених елемената музике и/или опере јесте сложени вишезначни однос између процеса компоновања, импровизације, композиције као довршеног производа и извођења, где је сам процес компоновања померен уназад на одлуку не само о избору предмета/инструмента, већ и на њихову диспозицију, која предодређује шта је могуће извести, то јест какав звук и структуру је могуће добити. Када је то одлучено, компоновање/импровизација/извођење улазе „у игру“, пресецају једни друге, уписују се једни у друге, чине те равни међусобног спајања/разилажења флуидним те је, сагласно томе да у одређеном степену сваки од тих домена подразумева елемент новог, и њихова резултанта (композиција) увек другачија.

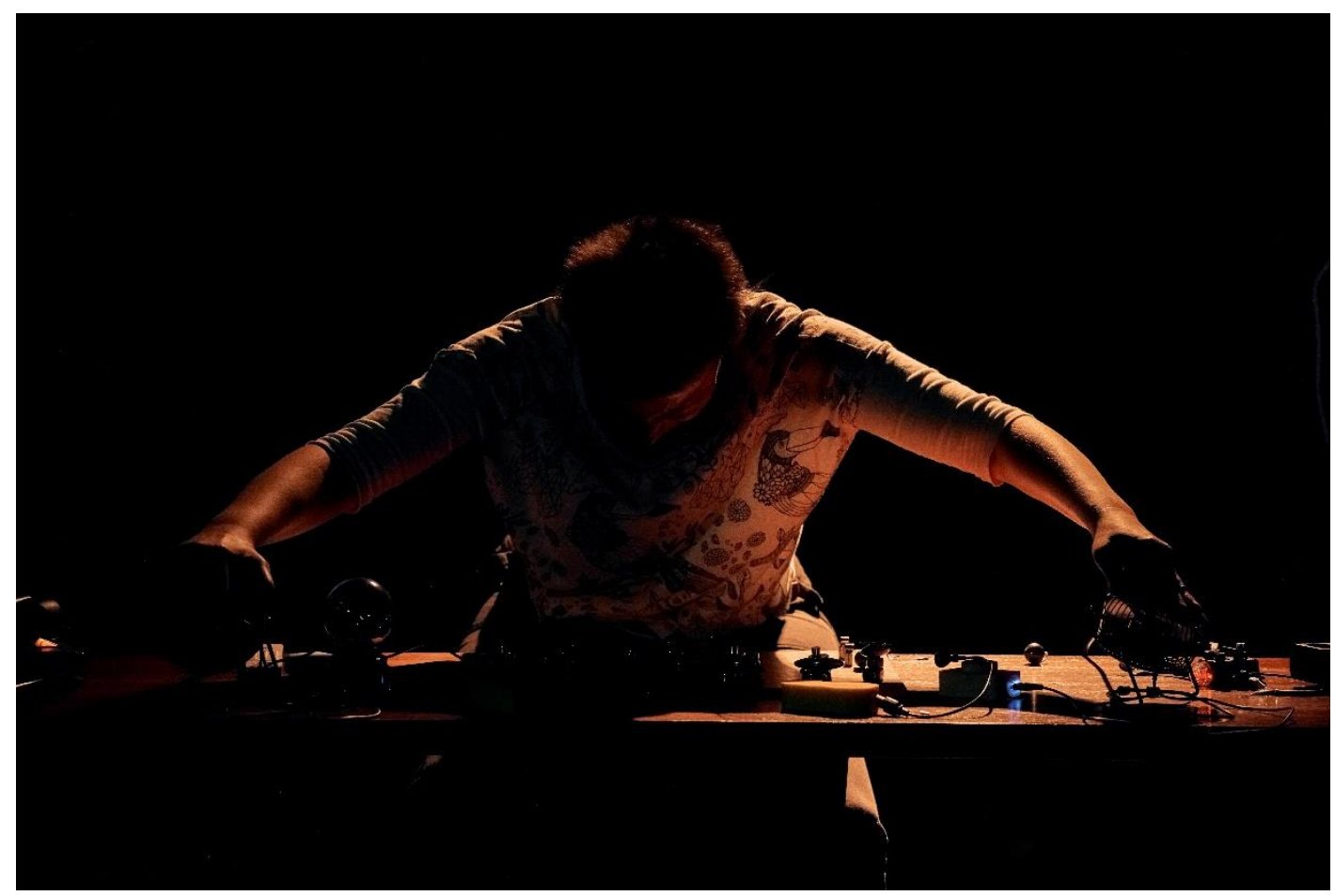

Фотографија 4: Јасна Величковић, Opera of Things (2019) [photo by Yoon Kwan Hee] 
Инсталирање оперског у овим радовима реализовано је на још један начин. Наиме, „тело“ оперске солисткиње/извођача/пуњача у арији било је изложено у истој просторији као и два анатомска цртежа (1745-46) Жака Фабијена Готијеа д’Аготија (Jacques Fabien Gautier d'Agoty), на којима је реалистично, са свим мускуларним и органским детаљима у дословности црвене боје, представљена анатомија говорног апарата на једном, и дисајног апарата на другом цртежу. Квартет пуњача је био у непосредној близини инсталације Singing Machine/Audition и техничких нацрта за Ричесову направу, а дует - у истој соби у којој и Кирхеров цртеж звучних аутоматона, репродукција гравуре Sirènes a voyelles et résonatours buccaux („Сирене са осмогласницима и усним резонаторима“, 1900) Жоржа Ренеа Мари Маража (Georges René Marie Marage) и интерактивна кинетичка скулптура A Truly Magical Moment („Истински магичан тренутак“) Адама Басанте. На такав начин добијене су три праве мале оперске сцене чији су гласови/тела имали и своје дводимензионалне тихе антиподе, све то у констелацији која се, упркос свим технолошким и медијским интервенцијама, преобликовањима и демонтирањима снажно показивала управо, како је то исказано у наслову Басантиног рада, као истински магична. За магију је, по Басанти, потребан пар који жели да буде (поново) уједињен, два ај-фона, апликација ФејсТајм, интернет и само минут времена: позивом на дате телефонске бројеве пар покреће инсталацију - кружно кретање телефонских апарата у темпу од лаганог до брзог и назад - уз сукцесивно надовезане фрагменате увертире Ромео и Јулија Петра Иљича Чајковског, Мадам Батерфлај Пучинија (Giacomo Puccini) и поп хита Reunited дуа Пичиз и Херб (Peaches and Herb).

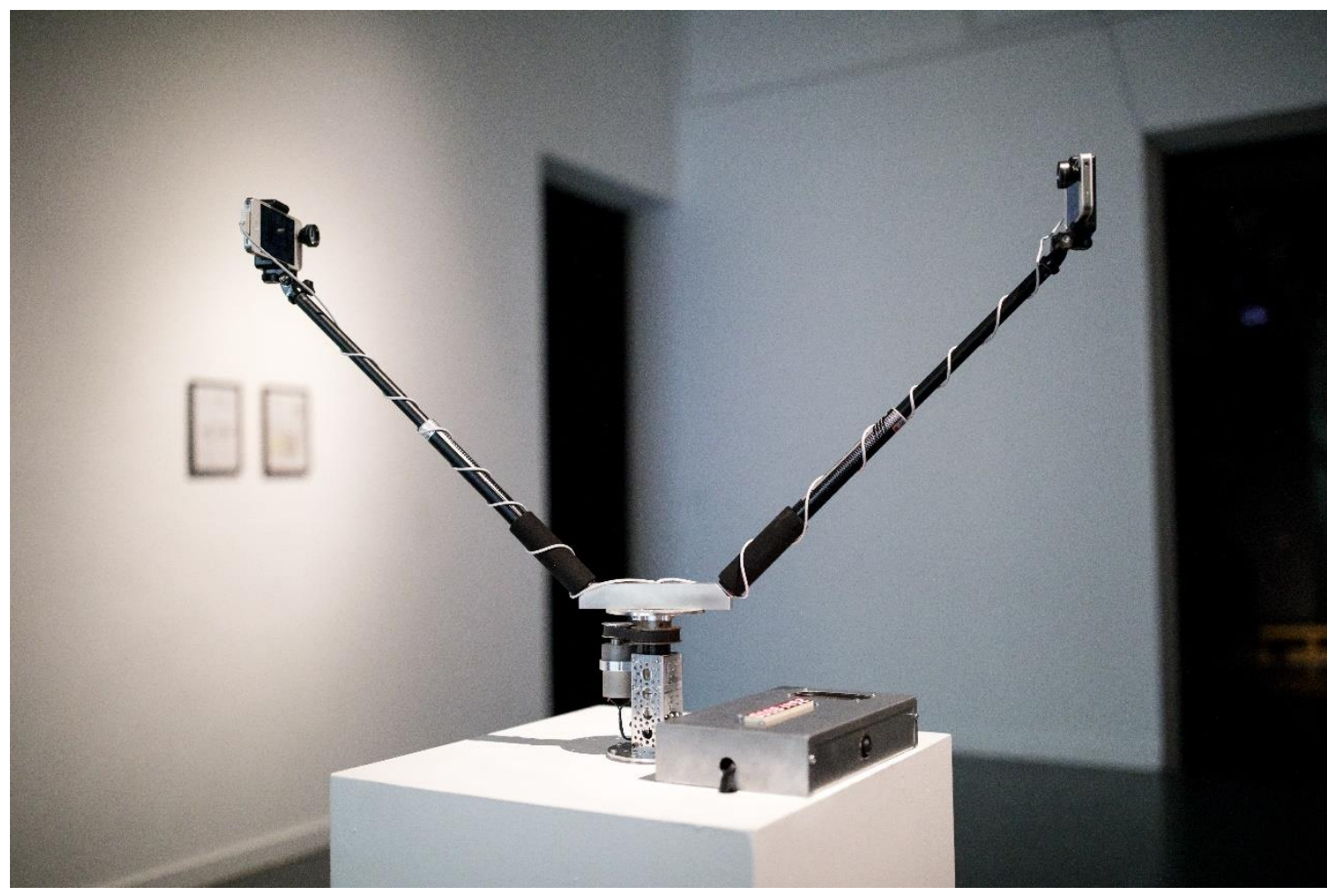

Фотографија 5: Адам Басанта, A Truly Magical Moment (2016), интерактивна кинетичка скулптура, [photo by Aad Hoogendoorn] 
Телефонски апарати, екранима окренути један према другом, поново - али у дирљивој инверзији - одигравају клишеизиране представе заљубљених парова око којих се свет окреће и време пролази док се они нетремице гледају право у очи, чула неосетљивих ни за шта око себе осим једно за друго (Фотографија 5). Та магична прикованост за објект жудње, који готово соматски осећамо као свој, а он нам измиче све даље и даље, можда јесте и поетизована срж ове целокупне приче о гласу који се одметнуо од свог (оперског) тела. Она ce, mutatis mutandis, транспонује и на поглед и ухо посетиоца који у представљеним креацијама пост-оперске магије треба (и може!) да пронађе свог пара и да се препусти чаролији.

\section{Цитирана дела}

Derida, Žak: Drugi pravac. Beograd: LAPIS, 1995.

Dolar, Mladen: Glas i ništa više. Prev. Iva Nenić. Beograd: Fedon, 2012.

Novak, Jelena: Operofilia. Beograd: Orion Art, 2018.

Tronchin, Lamberto et al.: „The marvellous sound world in the 'Phonurgia Nova' of Athanasius Kircher", The Journal of the Acoustical Society of America, 123(5), 2008, 4184-4190.

\section{Сажетак}

Изложба Пост-опера је сложен и провокативан кустоски и ауторски пројект који су потписале историчарка уметности Крис Дител и музиколошкиња и теоретичарка опере и медија Јелена Новак. Ова изложба је имала за циљ да, у међусобном сапостављању и огледању визуелних уметности, технологије и опере, преиспита вишезначне и променљиве релације између гласа и (људског) тела. У међусобном уодношавању ових домена глас је постављен као ексклузивни означитељ оператичности саме опере, а однос између гласа и тела као равноправан у процесу производње значења. Изложба је обухватила неколико жанровски и медијски различитих сегмената: поставку изложбе у галерији, периодичне „активације уживо“ у простору изложбе, у простору галерије или на одабраним „отвореним“ локацијама града, перформансе, вокалну радионицу и симпозијум.

Изложба је покренула три кључна питања. Прво, посреди је позиција кустоса као уметника и изложбе као форме уметности. У помаку од пуког стављања знака једнакости између чина селекције и чина стварања ка дубинској ауторефлексији подједнако процеса излагања, колико и самог стваралачког и извођачког процеса, кустоскиње су однос између ових категорија издигле како на ниво поетичког, тако и на раван методолошког принципа кустоског рада као уметничког рада. Друго, реч је о вишеструкости домена гласа у савременој уметности и култури. У концепту изложбе могла се јасно назрети упитаност над изрицањем певајућег и говорећег гласа, над политичношћу-дејственошћу гласа у савременом друштву и медијској култури престилизованих, полираних, heavily процесираних попевки данашњице. Глас се указао као означитељ маргинализације и разарајућих последица идентитетских политика, односа моћи дејњтвујућих у његовом растеловљеном присуству, невидиљивим каналима трансмисије и позицијама примаоца, релационе политике колективних идентитета конструисаних како у свакодневној тако и у дигиталној 'реалности'. Треће, изложба је проблематизовала вентрилоквистички јаз између певајућег тела и певаног гласа као оно што 'оперу чини оперском'. Ступајући у поље аутоматизованог и/или технолошки генерисаног транс- или постхуманог света, представљени радови су на узбудљив начин преиспитали критичну тачку ресемантизације односа између та два елузивна, али за оперу ипак конститутивна елемента. 